\title{
Vertical distributions of plutonium isotopes in marine sediment cores off the Fukushima coast after the Fukushima Dai-ichi Nuclear Power Plant accident
}

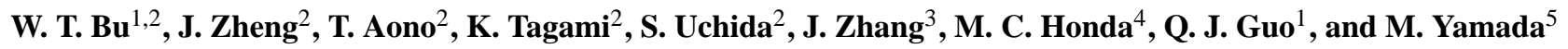 \\ ${ }^{1}$ State Key Laboratory of Nuclear Physics and Technology, School of Physics, Peking University, \\ Beijing 100871, China \\ ${ }^{2}$ Research Center of Radiation Protection, National Institute of Radiological Sciences, Anagawa 4-9-1, Inage, \\ Chiba 263-8555, Japan \\ ${ }^{3}$ Department of Environmental Biology and Chemistry, University of Toyama, 3190 Gofuku, Toyama 930-8555, Japan \\ ${ }^{4}$ Research Institute for Global Change, Japan Agency for Marine-Earth Science and Technology, 2-15 Natsushima, \\ Yokosuka 237-0061, Japan \\ ${ }^{5}$ Department of Radiation Chemistry, Institute of Radiation Emergency Medicine, Hirosaki University, 66-1 Hon-cho, \\ Hirosaki, Aomori 036-8564, Japan
}

Correspondence to: J. Zheng (jzheng@nirs.go.jp)

Received: 21 December 2012 - Published in Biogeosciences Discuss.: 10 January 2013

Revised: 22 March 2013 - Accepted: 22 March 2013 - Published: 15 April 2013

\begin{abstract}
The Fukushima Dai-ichi Nuclear Power Plant (FDNPP) accident led to the release of large amounts of radionuclides into the atmosphere as well as direct discharges into the sea. In contrast to the intensive studies on the distribution of the released high volatility fission products, such as ${ }^{131} \mathrm{I},{ }^{134} \mathrm{Cs}$ and ${ }^{137} \mathrm{Cs}$, similar studies of the actinides, especially the $\mathrm{Pu}$ isotopes, are limited. To obtain the vertical distribution of $\mathrm{Pu}$ isotopes in marine sediments and to better assess the possible contamination of $\mathrm{Pu}$ from the FDNPP accident in the marine environment, we determined the activities of ${ }^{239+240} \mathrm{Pu}$ and ${ }^{241} \mathrm{Pu}$ as well as the atom ratios of ${ }^{240} \mathrm{Pu} /{ }^{239} \mathrm{Pu}$ and ${ }^{241} \mathrm{Pu} /{ }^{239} \mathrm{Pu}$ in sediment core samples collected in the western North Pacific off Fukushima from July 2011 to July 2012. We also measured surface sediment samples collected from seven Japanese estuaries before the FNDPP accident to establish the comprehensive background baseline data. The observed results of both the $\mathrm{Pu}$ activities and the $\mathrm{Pu}$ atom ratios for the sediments in the western North Pacific were comparable to the baseline data, suggesting that the FDNPP accident did not cause detectable $\mathrm{Pu}$ contamination to the studied regions prior to the sampling time. The $\mathrm{Pu}$ isotopes in the western North Pacific $30 \mathrm{~km}$ off the Fukushima coast originated from
\end{abstract}

global fallout and Pacific Proving Ground close-in fallout.

\section{Introduction}

On 11 March 2011, a magnitude 9.0 earthquake, centered in the northwest Pacific about $130 \mathrm{~km}$ off the northeast coast of Japan, and the ensuing gigantic tsunami caused severe damage to the Fukushima Dai-ichi Nuclear Power Plant (FDNPP). The cooling systems of some of the nuclear reactor units failed, resulting in hydrogen explosions in the reactor buildings and venting of gases, which caused large releases of radionuclides into the atmosphere. For example, the total released amount of ${ }^{137} \mathrm{Cs}$ to the atmosphere from the FDNPP reactors has been estimated to be in the range of 9.9-36.6 PBq (Chino et al., 2011; Morino et al., 2011; Stohl et al., 2012). More than $70 \%$ of the released radionuclides were deposited over the North Pacific (Yoshida and Kanda, 2012). In addition, highly contaminated water with large amounts of radionuclides, originating from desperate attempts to prevent reactor cores meltdowns by injecting water into the reactor units, was directly leaked or discharged 
into the North Pacific Ocean (Buesseler et al., 2011; Inoue et al., 2012; Tsumune et al., 2012).

Intensive studies on the high volatility fission products released into the ocean, such as ${ }^{131} \mathrm{I},{ }^{134} \mathrm{Cs}$ and ${ }^{137} \mathrm{Cs}$, were carried out after the FDNPP accident, and data on the concentration and distribution of these products were immediately collected (Aoyama et al., 2013; Buesseler et al., 2011; Honda et al., 2012; Inoue et al., 2012). However, similar studies focusing on the possible released actinides, especially $\mathrm{Pu}$ isotopes, are limited. Pu isotopes are characterized by high chemical toxicity, radiotoxicity and long half-lives, and they have attracted much scientific and public concern. Investigating the impact of the FDNPP accident on the distribution of long half-live radionuclides in the environment is important for the long-term dose assessments (Yoshida and Kanda, 2012). In addition, as Pu isotopes are produced by the initial neutron capture reaction in ${ }^{238} \mathrm{U}$ in the nuclear reactors and directly used as the component of MOX fuel in the FDNPP unit 3 reactor (Burns et al., 2012), accurate determination of $\mathrm{Pu}$ isotopes in the environmental materials may provide important information to understand the reactors damages.

Abnormal atom ratios of ${ }^{240} \mathrm{Pu} /{ }^{239} \mathrm{Pu}(>0.3)$ and activity ratios of ${ }^{241} \mathrm{Pu} /{ }^{239+240} \mathrm{Pu}(>100)$ were reported in the surface soil and litter samples in the $20-30 \mathrm{~km}$ zone around the FDNPP, providing evidence for the atmospheric release of $\mathrm{Pu}$ into the terrestrial environment (Zheng et al., 2012a). Imanaka et al. (2012) and Yamamoto et al. (2012) also found ${ }^{238} \mathrm{Pu} /{ }^{239+240} \mathrm{Pu}$ activities ratios, higher than the global fallout value, for soil samples collected in Iitate Village and Okuma Town, at distances of $25-45 \mathrm{~km}$ from the plant. In the marine environment, we investigated the distribution of $\mathrm{Pu}$ isotopes in surface marine sediments in the Pacific $30 \mathrm{~km}$ off the FDNPP that were collected several months after the accident (Zheng et al., 2012b), and observed no significant variation in ${ }^{239+240} \mathrm{Pu}$ activity and ${ }^{240} \mathrm{Pu} /{ }^{239} \mathrm{Pu}$ atom ratio compared with previously reported values in marine sediments in the western North Pacific. Meanwhile, Sakaguchi et al. (2012) found that Pu concentration in seawater sampled from the Pacific Ocean $50 \mathrm{~km}$ from the FDNPP site showed no extra component from the accident. However, the possible long-term $\mathrm{Pu}$ contamination in the marine environment remains unknown as no information is currently available on the $\mathrm{Pu}$ isotopes in the released radioactive liquids and in the FDNPP near-coastal (within $30 \mathrm{~km}$ ) marine environment. Pu isotopes in the western North Pacific off Japan can be transported rapidly by oceanic currents, e.g. the Oyashio Current and the Kuroshio Current, and undergo advection and mixing (Buesseler et al., 2012; Lee et al., 2005; Zheng and Yamada, 2005). Thus, the possible Pu contamination from the accident needs further investigation before reaching a reliable conclusion.

Investigating the concentration of radionuclides in the marine sediments is important for the radiobiological assessment in the marine environment as the sediments are a possible source of continued contamination for the marine biota
(Buesseler, 2012). The radiocesium $\left({ }^{134} \mathrm{Cs}\right.$ and $\left.{ }^{137} \mathrm{Cs}\right)$ originating from the accident was detected in the sinking particles collected from the deep sea (water depth $4810 \mathrm{~m}$ ) in the western North Pacific, one month after the accident, suggesting the quick transportation of radionuclides to the deep sea via atmospheric deposition (Honda et al., 2013). Otasaka and Kobayashi (2012) observed that dissolved radiocesium from the FDNPP accident was advected southward where it deposited onto sediments along the Ibaraki coast early in the accident. $\mathrm{Pu}$ isotopes are more particle reactive than $\mathrm{Cs}$ and the sediment-water distribution coefficient $\left(K_{\mathrm{d}}\right.$ value $)$ of $\mathrm{Pu}$ is two orders of magnitude higher than that of Cs (IAEA, 2004). In mid-April 1986, by a coincidence of timing, IAEAMEL scientists moored automated time series sediment traps in the Ligurian Sea, and they found that in one month after the accident more than $50 \%$ of the total ${ }^{239+240} \mathrm{Pu}$ inventory originating from Chernobyl and deposited in that region had transited through $200 \mathrm{~m}$ depth, while only $0.2 \%$ of the corresponding ${ }^{137} \mathrm{Cs}$ deposition did so (Povinec et al., 1996). In the North Pacific, the Chernobyl-derived radiocesium was detected in the sinking particles collected at a depth of $780 \mathrm{~m}$ two months after the Chernobyl accident (Kusakabe et al., 1988). The resident time of Pu isotopes in the North Pacific was much shorter than that of radiocesium (Fowler et al., 1983; Honda et al., 2013). Thus Pu isotopes released from the FNDPP accident could be more quickly incorporated into sediments by the scavenging process than $\mathrm{Cs}$, and the determination of $\mathrm{Pu}$ isotopes in the sediments should give reliable information about $\mathrm{Pu}$ contamination in the marine environment.

To compare the distributions of $\mathrm{Pu}$ isotopes in the marine sediments before and after the FNDPP accident, the background dataset needs to be established. Due to the potential applications of $\mathrm{Pu}$ isotopes as a chemical tracer for oceanic processes and as a source identifier for radioactive contamination, over the past decades, the distribution of Pu isotopes in the western North Pacific and its marginal seas have been studied intensively (Buesseler, 1997; Dong et al., 2010; Hong et al., 1999; Ito et al., 2007; Kim et al., 2003; Lee et al., 1998, 2003, 2004, 2005; Lindahl et al., 2011; Liu et al., 2011a; Moon et al., 2003; Nagaya and Nakamura, 1992; Oikawa et al., 2011; Otosaka et al., 2006; Pettersson et al., 1999; Wang and Yamada, 2005; Zheng and Yamada, 2005, 2006b, c). For the Japanese near-coastal marine environment, especially the estuaries, leaching of contaminated soils is another potential pathway for radioactive contamination in addition to the atmospheric deposition from the accident plume and the direct release of contaminated plant cooling waters (Bailly du Bois et al., 2012). Before the accident, ${ }^{239+240} \mathrm{Pu}$ activity and ${ }^{240} \mathrm{Pu} /{ }^{239} \mathrm{Pu}$ atom ratio in five estuaries in western and northern Japan had been investigated (Liu et al., 2011b; NIRS, 2010). However, for estuaries in eastern Japan, where it is geographically more possible to be contaminated from the FDNPP accident, the background data for Pu contamination assessment are limited. 


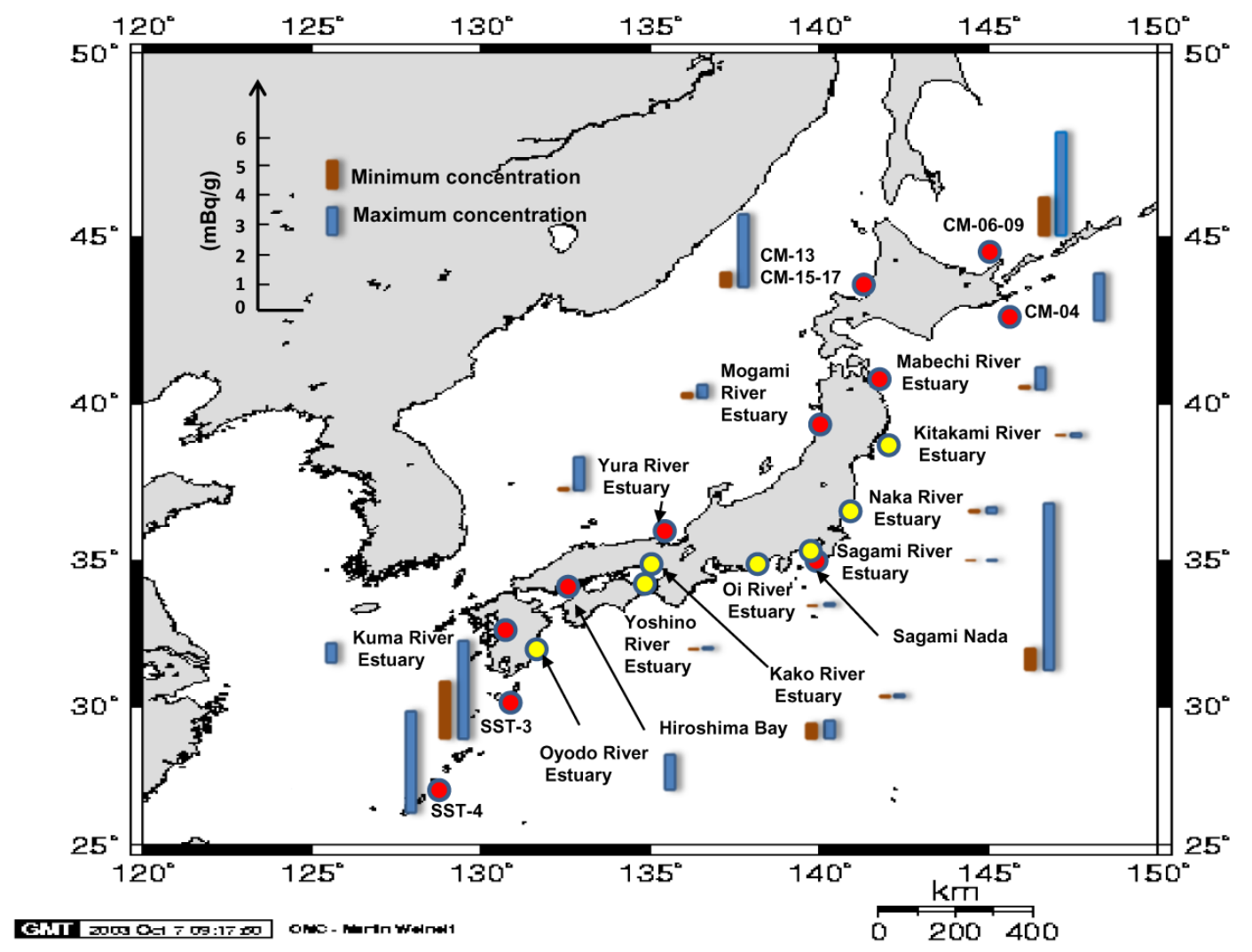

Fig. 1. Map showing the Japanese estuaries and the Pu concentration $\left(\mathrm{mBq}^{-1}\right)$ in the surface sediments $(0-2 \mathrm{~cm})$ in the Japanese near-coast marine environment. The yellow circled sites represent the sampling sites in this study. The red circled sites are from the literature (NIRS, 2010; Zheng and Yamada, 2005, 2006b, c). The surface sediment Pu concentration range was between $0.003-5.81 \mathrm{mBq}^{-1}$.

Our previous work reported the rapid assessment focused on only surface sediments (Zheng et al., 2012a). Although no detectable $\mathrm{Pu}$ was found, the possibility existed that quick downward migration of the deposited $\mathrm{Pu}$ in surface sediments could have occurred by diffusion and bioturbation effect since the sampling time was several months after the accident. Therefore, the vertical distributions of $\mathrm{Pu}$ in the sediment cores are important for a more complete assessment. In this work, we first measured Pu isotope concentrations in the surface sediments from seven eastern Japan estuaries facing the North Pacific, using samples collected from 2008 to 2010. Then we summarized the published results to establish the comprehensive baseline data of Pu distribution in the western North Pacific and its marginal seas. Next we determined the vertical distribution of $\mathrm{Pu}$ activities $\left({ }^{239+240} \mathrm{Pu}\right.$ and $\left.{ }^{241} \mathrm{Pu}\right)$ and $\mathrm{Pu}$ atom ratios $\left({ }^{240} \mathrm{Pu} /{ }^{239} \mathrm{Pu}\right.$ and $\left.{ }^{241} \mathrm{Pu} /{ }^{239} \mathrm{Pu}\right)$ in five sediment cores, collected in the western North Pacific after the FDNPP accident. Finally, we compared our obtained results with the baseline data to assess the impact of the possible $\mathrm{Pu}$ contamination in the marine environment due to the FDNPP accident.

\section{Materials and methods}

\subsection{Study area and sampling}

Surface sediment samples $(0-2 \mathrm{~cm})$ were collected from seven estuaries (Sagami River, Oyodo River, Yoshino River, Oi River, Naka River, Kitakami River and Kako River) in eastern Japan facing the North Pacific during the years 2008 to 2010. For each estuary, 24 samples were collected. Five sediment core samples $\left(\mathrm{ES} 4,37^{\circ} 53.00^{\prime} \mathrm{N}, 143^{\circ} 35.00^{\prime} \mathrm{E}\right.$; FS1, 37 $20.00^{\prime} \mathrm{N}$, $141^{\circ} 25.00^{\prime} \mathrm{E} ; \quad \mathrm{MC} 5, \quad 37^{\circ} 35.01^{\prime} \mathrm{N}, 141^{\circ} 30.95^{\prime} \mathrm{E} ; \mathrm{MC} 1$, $36^{\circ} 28.97^{\prime} \mathrm{N}, 141^{\circ} 29.93^{\prime} \mathrm{E} ; \mathrm{F} 1,36^{\circ} 29.09^{\prime} \mathrm{N}, 141^{\circ} 30.01^{\prime} \mathrm{E}$ ) were collected by a multiple corer in the western North Pacific Ocean off the FDNPP site during the three cruises of MR-11-05, KH-11-07 and MR-12-02 from July 2011 to July 2012. The core samples were cut into $0.5 \mathrm{~cm}$ or $1 \mathrm{~cm}$ segments and stored in an on-board refrigerator until brought back to the land-based laboratory. The locations of the surface sediment sampling sites and the sediment core sampling sites in this study are shown in Figs. 1 and 2, respectively. 


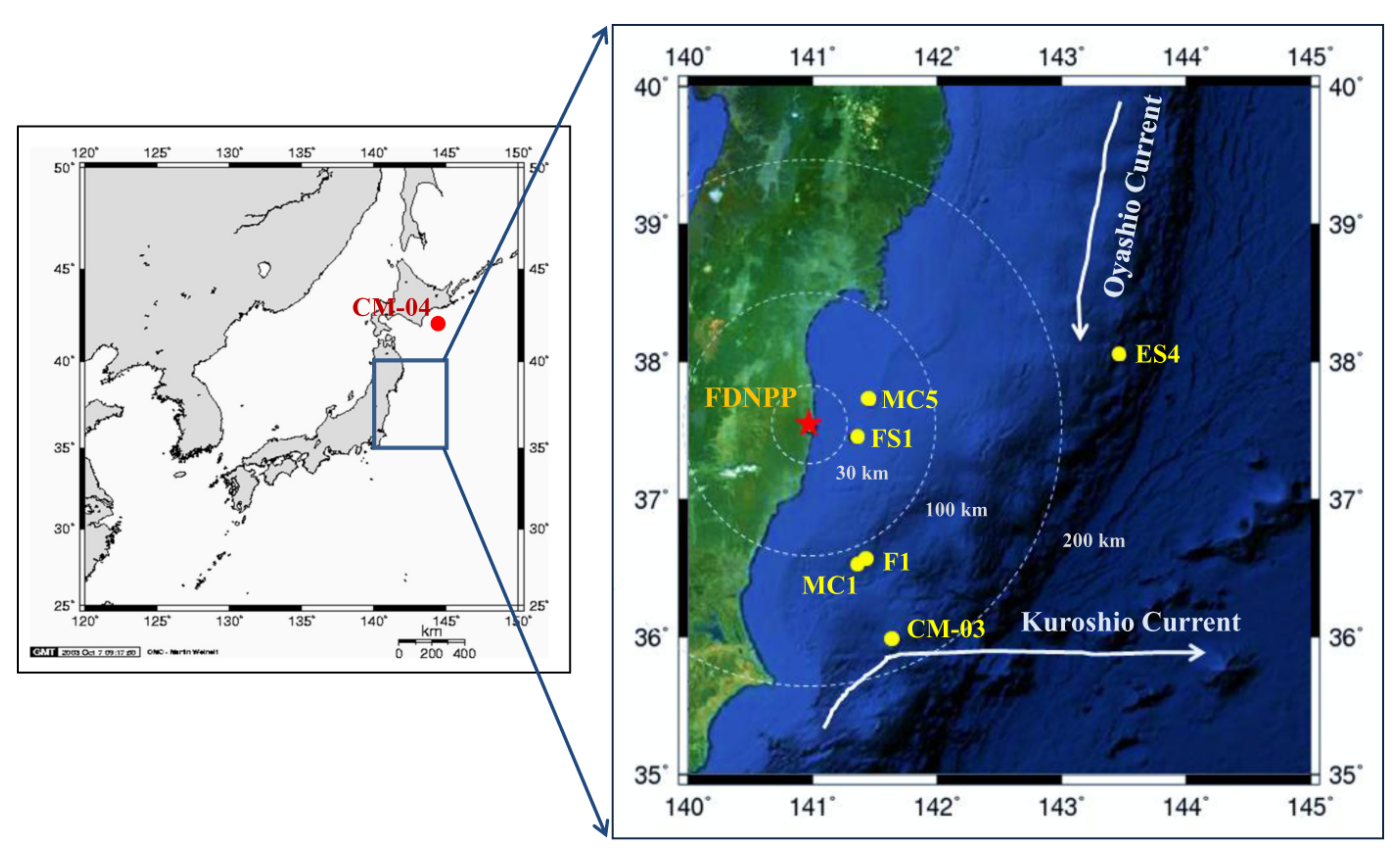

Fig. 2. Map showing the locations of the sediment sampling sites in the western North Pacific and the Kuroshio and Oyashio Currents. Stations CM-04 and CM-03 are from Zheng and Yamada (2006b).

\subsection{Analytical procedure}

We modified the method for sample preparation from the literature work (Liao et al., 2008). Briefly, the sediment samples were dried at $105^{\circ} \mathrm{C}$ for $24 \mathrm{~h}$. Then they were placed in ceramic crucibles and ashed in a muffle furnace at $600{ }^{\circ} \mathrm{C}$ for $5 \mathrm{~h}$. The ignition loss in each sample was determined by the decrease in sample weight before and after the ashing process. About $2.0 \mathrm{~g}$ dried sample was weighed out and spiked with $100 \mu \mathrm{L}$ (ca. $1 \mathrm{pg}{ }^{242} \mathrm{Pu}$ ) standard ${ }^{242} \mathrm{Pu}$ solution with a traceability to CRM 130 (plutonium spike assay and isotopic standard, New Brunswick Laboratory, USA) as yield monitor. The extraction of $\mathrm{Pu}$ was performed in a tightly covered Teflon tube with $20 \mathrm{~mL}$ concentrated $\mathrm{HNO}_{3}$ on a hot plate at $180-200^{\circ} \mathrm{C}$ for at least $4 \mathrm{~h}$. A two-stage anion-exchange chromatographic method using AG $1 \mathrm{X} 8$ and AG MP-1M resins was employed to separate $\mathrm{U}$ and $\mathrm{Pu}$ and further purify $\mathrm{Pu}$ (Liao et al., 2008). The final sample was prepared in $0.8 \mathrm{~mL} 4 \% \mathrm{HNO}_{3}$ media for Pu isotope analysis. The chemical yield of $\mathrm{Pu}$ for this employed sample preparation method was estimated to be in the range of $53 \%$ to $85 \%$ with a mean of $66 \% \pm 10 \%$.

The measurement of the concentration of $\mathrm{Pu}$ isotopes and $\mathrm{Pu}$ atomic ratios was done with a double-focusing SF-ICPMS (Element 2, Thermo Finnigan, Bremen, Germany). An APEX-Q high-efficiency sample introduction system (Elemental Scientific Inc., Omaha, NE, USA) with membrane desolvation unit (ACM) and a conical concentric nebulizer was used. We used the SF-ICP-MS in the low resolution (LR) mode to utilize the maximum instrument sensitivity.
In addition, we replaced the normal skimmer cone with a high-efficiency cone (X-cone, Thermo Finnigan) to further increase the sensitivity of the SF-ICP-MS. All the measurements were made in the self-aspirating mode to reduce the risk of contamination by the peristaltic pump tubing. The detailed operation conditions and measurement parameters for this measuring method were described elsewhere (Zheng and Yamada, 2006a). A Pu isotope standard solution (NBS-947) with a known ${ }^{240} \mathrm{Pu} /{ }^{239} \mathrm{Pu}$ atom ratio was used for mass bias correction. Two ocean sediment reference materials (NIST4357 and IAEA-368) were used for analytical method validation. The analytical results of the reference materials were in good agreement with the certified activity values and the reported $\mathrm{Pu}$ atom ratio values (Table $1 \mathrm{~S}$, see Supplement).

\section{Results and discussion}

\subsection{Baseline data for the Pu distribution in the western North Pacific and its marginal seas before the FDNPP accident}

$\mathrm{Pu}$ isotopes in the western North Pacific and its marginal seas could be attributed to the global fallout and the Pacific Proving Ground (PPG) close-in fallout before the FNDPP accident. The PPG was the name used to describe a number of sites in the Marshall Islands and a few other sites in the Pacific Ocean, used by the United States to conduct nuclear testing between 1946 and 1962. The global fallout $\mathrm{Pu}$ has a ${ }^{240} \mathrm{Pu} /{ }^{239} \mathrm{Pu}$ atom ratio of 0.18 (Bowen et al., 1980; Kelley et al., 1999; Livingston and Povinec, 2002), while 
the PPG close-in fallout has been characterized by a higher ${ }^{240} \mathrm{Pu} /{ }^{239} \mathrm{Pu}$ atom ratio ( $>0.30$ ) (Buesseler, 1999; Diamond et al., 1960; Muramatsu et al., 2001).

The ${ }^{239+240} \mathrm{Pu}$ activities and ${ }^{240} \mathrm{Pu} /{ }^{239} \mathrm{Pu}$ atom ratios in the surface sediments in Japanese estuaries as well as Tokyo Bay, Sagami Bay and Hiroshima Bay are summarized in Table 1 and the ${ }^{239+240} \mathrm{Pu}$ activities are presented in Fig. 1. As shown in Fig. 1, the concentration of ${ }^{239+240} \mathrm{Pu}$ activity in the Japanese estuaries is relatively low, ranging from 0.003 to $5.81 \mathrm{mBq} \mathrm{g}^{-1}$. In particular, for the estuaries off the eastern coast of Japan facing the North Pacific, investigated in this study, the concentration of ${ }^{239+240} \mathrm{Pu}$ activities were typically below $0.400 \mathrm{mBq} \mathrm{g}^{-1}$ (Table $2 \mathrm{~S}$, Supplement). The highest concentration $\left(5.81 \mathrm{mBq} \mathrm{g}^{-1}\right)$ of ${ }^{239+240} \mathrm{Pu}$ activity was reported in the surface sediment of Sagami Nada (Zheng and Yamada, 2004). For all the estuary sediments investigated in this study, the ${ }^{241} \mathrm{Pu}$ activity was below the detection limit $\left(2 \mathrm{mBq} \mathrm{g}^{-1}\right)$ of the SF-ICP-MS.

The ${ }^{240} \mathrm{Pu} /{ }^{239} \mathrm{Pu}$ atom ratios in the Japanese near-coastal surface sediments are shown in Fig. 3, and they ranged from 0.170 to 0.270 . All the values were generally higher than the value of global fallout, except for CM-04 and CM-0608 in northern Japan. Zheng and Yamada (2006b) suggested CM-04 and CM-06-08 received only trace amounts of PPG close-in fallout $\mathrm{Pu}$ via atmospheric deposition. An average ${ }^{240} \mathrm{Pu} /{ }^{239} \mathrm{Pu}$ atom ratio of $0.231 \pm 0.025(n=36)$ was obtained for the Japanese eastern estuaries facing the North Pacific, which indicated the mixing of global fallout $\mathrm{Pu}$ and PPG close-in fallout Pu.

A more comprehensive summarization about the distribution of $\mathrm{Pu}$ isotopes in the western North Pacific and its marginal seas in the literature (Buesseler, 1997; Dong et al., 2010; Hong et al., 1999; Ito et al., 2007; Kim et al., 2003; Lee et al., 1998, 2003, 2004, 2005; Liu et al., 2011a; Moon et al., 2003; Nagaya and Nakamura, 1992; Oikawa et al., 2011; Otosaka et al., 2006; Pettersson et al., 1999; Wang and Yamada, 2005; Yamamoto et al., 1990; Zheng and Yamada, 2005, 2006b, c) is given in Table 2. The concentration of ${ }^{239+240} \mathrm{Pu}$ activity and ${ }^{240} \mathrm{Pu} /{ }^{239} \mathrm{Pu}$ atom ratio in the surface sediments ranged from 0.002 to $5.38 \mathrm{mBq} \mathrm{g}^{-1}$ and from 0.150 to 0.281 , respectively, except in the surface sediment collected near the Bikini Atoll, where the high concentration of $12.5 \mathrm{mBq} \mathrm{g}^{-1}$ and high atom ratio of 0.336 have been reported (Buesseler, 1997; Lee et al., 2005). In the Okinawa Trough and Sagami Bay, the ${ }^{240} \mathrm{Pu} /{ }^{239} \mathrm{Pu}$ atom ratios were found to increase with depth with a maximum of $0.30-0.33$ in the deeper layer $(>5 \mathrm{~cm}$ ) sediments (Lee et al., 2004; Wang and Yamada, 2005; Zheng and Yamada, 2006b), indicating clearly the early deposition of the PPG close-in fallout Pu.

Historically, ${ }^{241} \mathrm{Pu}$ was released into the environment by the nuclear weapon testing mainly conducted $50 \mathrm{yr}$ ago and its half-live is relatively short (14.4 yr), so the current activity of ${ }^{241} \mathrm{Pu}$ in the environment is quite low. Yamamoto et al. (1990) determined the Pu isotopes in the sediments collected from the Nyu Bay in the Japan Sea, and they found that

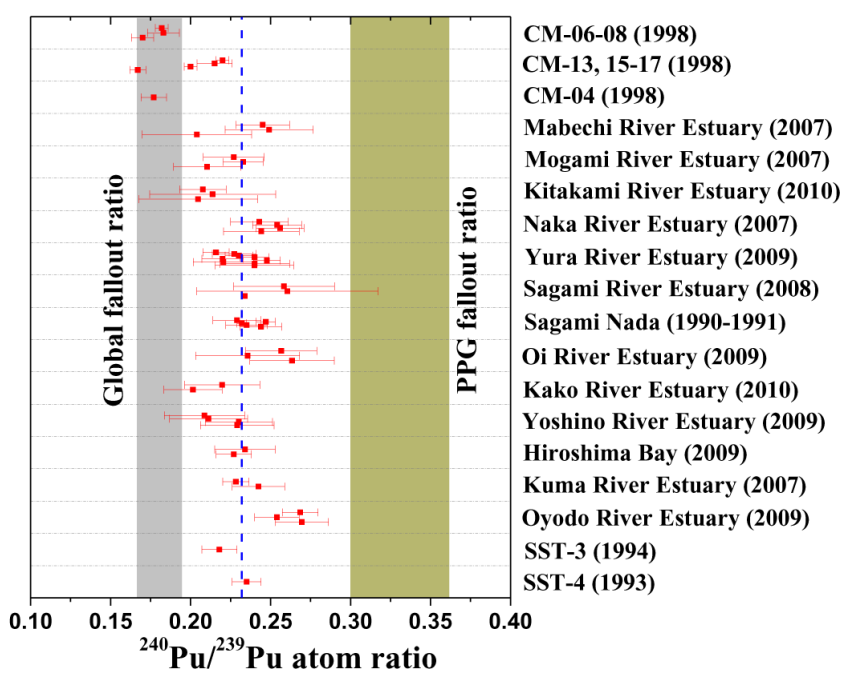

Fig. 3. The ${ }^{240} \mathrm{Pu} /{ }^{239} \mathrm{Pu}$ atom ratio distribution in Japanese nearcoast surface sediments. The years shown in the brackets are the sampling dates. The areas shaded in grey and light green represent the ${ }^{240} \mathrm{Pu} /{ }^{239} \mathrm{Pu}$ atom ratio ranges of global fallout $(0.180 \pm 0.014)$ and PPG close-in fallout $(0.30-0.36)$, respectively. The atom ratio ranged from $0.170-0.270$. For the eastern estuaries facing the North Pacific, the average ${ }^{240} \mathrm{Pu} /{ }^{239} \mathrm{Pu}$ atom ratio was $0.231 \pm 0.025(n=$ 36 ). The blue dotted line is the mean atom ratio value (0.231). Data for CM-06-08, CM-13, 15-17, Mabechi River Estuary, Mogami River Estuary, Yura River Estuary, Kuma River Estuary, SST-3 and SST-4 are cited from the literature (NIRS, 2010; Zheng and Yamada, 2005, 2006b, c).

the ${ }^{241} \mathrm{Pu}$ activities and the ${ }^{241} \mathrm{Pu} /{ }^{239+240} \mathrm{Pu}$ activity ratios ranged from $4.5 \mathrm{mBq} \mathrm{g}^{-1}$ to $7.5 \mathrm{mBq} \mathrm{g}^{-1}$ and from 1.2 to 1.9 , respectively. (For all the values related to ${ }^{241} \mathrm{Pu}$ discussed here, decay corrections have been made to 11 March 2011.) Similarly, Zheng and Yamada (2008) observed a ${ }^{241} \mathrm{Pu}$ activity of $8.4 \mathrm{mBqg}^{-1}$ and a ${ }^{241} \mathrm{Pu} / 239+240 \mathrm{Pu}$ activity ratio of 1.2 at a depth of $18-20 \mathrm{~cm}$ in a sediment core collected from Sagami Bay. More comprehensive investigations were conducted by the Japanese government on the distribution of $\mathrm{Pu}$ isotopes in the surface marine sediments off Japan, and the results for the ${ }^{241} \mathrm{Pu}$ activity and ${ }^{241} \mathrm{Pu} /{ }^{239+240} \mathrm{Pu}$ activity ratio in the surface sediments were typically below $3.3 \mathrm{mBq} \mathrm{g}^{-1}$ and 1.1, respectively (MEXT, 2008). Due to the influence of the PPG close-in fallout, high ${ }^{241} \mathrm{Pu}$ activities (up to $19.3-33.4 \mathrm{mBqg}^{-1}$ ) and the ${ }^{241} \mathrm{Pu} /{ }^{239+240} \mathrm{Pu}$ activity ratios (2.2-2.7) were observed in the sediments near the Bikini Atoll (Lee et al., 2005).

For the inventory of ${ }^{239+240} \mathrm{Pu}$, a wide range of values $\left(1.38-693.33 \mathrm{~Bq} \mathrm{~m}^{-2}\right)$ have been observed. The vertical distribution of $\mathrm{Pu}$ isotopes in the sediments varied significantly due to the difference of bottom topography and sedimentation dynamics. For example, the enhanced particle scavenging in the continental margin resulted in higher Pu inventories in the sediments in the Okhotsk Sea $\left(81-271 \mathrm{~Bq} \mathrm{~m}^{-2}\right)$ compared to those from the global fallout areas (Zheng and 
Table 1. Summary of the distributions of ${ }^{239+240} \mathrm{Pu}$ activity and ${ }^{240} \mathrm{Pu} /{ }^{239} \mathrm{Pu}$ atom ratio in the surface sediments $(0-2 \mathrm{~cm})$ from Japanese estuaries.

\begin{tabular}{|c|c|c|c|c|c|}
\hline Area & Location & Sampling date & $\begin{array}{r}\text { Surface }{ }^{239+240} \mathrm{Pu} \text { activity } \\
\left(\mathrm{mBqg}^{-1}\right)\end{array}$ & $\begin{array}{r}\text { Surface }{ }^{240} \mathrm{Pu} /{ }^{239} \mathrm{Pu} \\
\text { atom ratio }\end{array}$ & Reference \\
\hline Mabechi River Estuary & $40^{\circ} 32-35^{\prime} \mathrm{N}, 141^{\circ} 31-36^{\prime} \mathrm{E}$ & 2007 & $0.110-0.811$ & $0.204-0.249$ & NIRS (2010) \\
\hline Mogami River Estuary & $38^{\circ} 55-57^{\prime} \mathrm{N}, 139^{\circ} 46-47^{\prime} \mathrm{E}$ & 2007 & $0.187-0.478$ & $0.201-0.233$ & NIRS (2010) \\
\hline Yura River Estuary & $35^{\circ} 31-35^{\prime} \mathrm{N}, 135^{\circ} 16-20^{\prime} \mathrm{E}$ & 2007 & $0.122-1.191$ & $0.216-0.248$ & NIRS (2010) \\
\hline Kuma River Estuary & $32^{\circ} 22-27^{\prime} \mathrm{N}, 130^{\circ} 28-31^{\prime} \mathrm{E}$ & 2007 & $0.537-0.708$ & $0.228-0.242$ & NIRS (2010) \\
\hline Tokyo Bay & $35^{\circ} 12-19^{\prime} \mathrm{N}, 139-140^{\circ} \mathrm{E}$ & 1988 & $1.05-2.66$ & ND & Yamada and Nagaya (2000) \\
\hline Sagami Bay & $35^{\circ} 12-35^{\prime} \mathrm{N}, 139-140^{\circ} \mathrm{E}$ & 1990-1991 & $0.77-5.81$ & $0.232-0.244$ & Zheng and Yamada (2004) \\
\hline Hiroshima Bay & $34^{\circ} 11.5-18.5^{\prime} \mathrm{N}, 132^{\circ} 20.5-22.0^{\prime} \mathrm{E}$ & 2009 & $0.556-0.677$ & $0.224-0.239$ & Liu et al. (2011b) \\
\hline Sagami River Estuary & $35^{\circ} 18-20^{\prime} \mathrm{N}, 139^{\circ} 22-23^{\prime} \mathrm{E}$ & 2008 & $0.010-0.077$ & $0.258-0.261$ & This study \\
\hline Oyodo River Estuary & $31^{\circ} 53-54^{\prime} \mathrm{N}, 131^{\circ} 28-30^{\prime} \mathrm{E}$ & 2009 & $0.196-0.346$ & $0.254-0.270$ & This study \\
\hline Yoshino River Estuary & $34^{\circ} 4-5^{\prime} \mathrm{N}, 134^{\circ} 36-38^{\prime} \mathrm{E}$ & 2009 & $0.060-0.114$ & $0.209-0.231$ & This study \\
\hline Oi River Estuary & $34^{\circ} 46^{\prime} \mathrm{N}, 138^{\circ} 18-19^{\prime} \mathrm{E}$ & 2009 & $0.003-0.005$ & $0.236-0.264$ & This study \\
\hline Naka River Estuary & $36^{\circ} 20-21^{\prime} \mathrm{N}, 140^{\circ} 35-38^{\prime} \mathrm{E}$ & 2009 & $0.117-0.351$ & $0.243-0.246$ & This study \\
\hline Kitakami River Estuary & $38^{\circ} 34-35^{\prime} \mathrm{N}, 141^{\circ} 28-30^{\prime} \mathrm{E}$ & 2010 & $0.050-0.172$ & $0.205-0.214$ & This study \\
\hline Kako River Estuary & $34^{\circ} 42-44^{\prime} \mathrm{N}, 134^{\circ} 47-49^{\prime} \mathrm{E}$ & 2010 & $0.090-0.129$ & $0.202-0.220$ & This study \\
\hline
\end{tabular}

ND: not determined.

Table 2. Summary of the distributions of ${ }^{239+240} \mathrm{Pu}$ activity and ${ }^{240} \mathrm{Pu} /{ }^{239} \mathrm{Pu}$ atom ratio in sediments from the western North Pacific and its marginal seas.

\begin{tabular}{|c|c|c|c|c|c|c|c|c|}
\hline Area & Location & $\begin{array}{r}\text { Sampling } \\
\text { date }\end{array}$ & $\begin{array}{r}\text { Water depth } \\
(\mathrm{m})\end{array}$ & $\begin{array}{r}\text { Surface }{ }^{239+240} \mathrm{Pu} \\
\text { activity }\left(\mathrm{mBqg}^{-1}\right)^{\mathrm{a}}\end{array}$ & $\begin{array}{r}\text { Surface }{ }^{240} \mathrm{Pu} /{ }^{239} \mathrm{Pu} \\
\text { atom ratio }\end{array}$ & $\begin{array}{r}\text { Vertical }{ }^{240} \mathrm{Pu} /{ }^{239} \mathrm{Pu} \\
\text { atom ratio range }\end{array}$ & $\begin{array}{r}{ }^{239+240} \mathrm{Pu} \text { inventory } \\
\left(\mathrm{Bq} \mathrm{m}^{-2}\right)\end{array}$ & Reference \\
\hline West Caroline Basin & $2-5^{\circ} \mathrm{N}, 137^{\circ} \mathrm{E}$ & 1992 & $4157-4629$ & $0.08-0.20$ & ND & ND & $6.82-8.95$ & Moon et al. (2003) \\
\hline Solu Sea & $8.9^{\circ} \mathrm{N}, 121.5^{\circ} \mathrm{E}$ & 1996 & 4988 & $0.015-0.508$ & $0.257-0.281$ & $0.257-0.281$ & 1.38 & Dong et al. (2010) \\
\hline Near Bikini Atoll & $11^{\circ} 26^{\prime} \mathrm{N}, 164^{\circ} 52^{\prime} \mathrm{E}$ & 1997 & $\mathrm{ND}$ & $9.0-12.5$ & $0.239-0.242$ & $0.133-0.388$ & 130 & Lee et al. (2005) \\
\hline Near Bikini Atoll & $7^{\circ} 03.2^{\prime} \mathrm{N}, 164^{\circ} 47.3^{\prime} \mathrm{E}$ & 1978 & 5925 & $\mathrm{ND}$ & $0.336 \pm 0.012$ & ND & ND & Buesseler (1997) \\
\hline South China Sea & $15.5^{\circ} \mathrm{N}, 115.3^{\circ} \mathrm{E}$ & 1997 & 4234 & $0.099-0.157$ & $0.228-0.243$ & $0.227-0.300$ & 3.75 & Dong et al. (2010) \\
\hline Northwest-central Basin & $15-35^{\circ} \mathrm{N}, 145-159^{\circ} \mathrm{E}$ & 1997 & $5390-5924$ & $0.15-5.38$ & ND & ND & $2.8-71.8$ & Moon et al. (2003) \\
\hline Southern Okinawa Trough & $24-25^{\circ} \mathrm{N}, 122-123^{\circ} \mathrm{E}$ & 2000-2003 & $>1000$ & $1.3-3.0$ & $0.23-0.25$ & $0.2-0.33$ & $201.67-693.33$ & Lee et al. (2004) \\
\hline Okinawa Trough & $27-29^{\circ} \mathrm{N}, 126-128^{\circ} \mathrm{E}$ & $1992-1995$ & 999-1080 & $0.775-2.496$ & $0.210-0.261$ & $0.210-0.320$ & $32.5-47.2$ & Wang and Yamada (2005) \\
\hline East China Sea & $28-32^{\circ} \mathrm{N}, 123-127^{\circ} \mathrm{E}$ & 1992-1995 & $50-127$ & $0.250-1.160$ & $0.251-0.261$ & $0.236-0.297$ & $60.9-101$ & Wang and Yamada (2005) \\
\hline Yangtze River Estuary & $29-33^{\circ} \mathrm{N}, 121-125^{\circ} \mathrm{E}$ & 2006 & $10-70$ & $0.05-0.76$ & $0.22-0.26$ & $0.190-0.319$ & 387 & Liu et al. (2011a) \\
\hline East China Sea & $26-30^{\circ} \mathrm{N}, 127-131^{\circ} \mathrm{E}$ & 1993-1994 & $1830-1870$ & $1.25-3.56$ & $0.218-0.235$ & $0.218-0.247$ & $14.8-42$ & Zheng and Yamada (2006c) \\
\hline East China Sea and the Yellow Sea & $25-35^{\circ} \mathrm{N}, 122-124^{\circ} \mathrm{E}$ & 1987 & $37-2170$ & $0.107-0.467$ & ND & ND & $8.9-79.9$ & Nagaya and Nakamura (1992) \\
\hline East Sea & $20-45^{\circ} \mathrm{N}, 140-145^{\circ} \mathrm{E}$ & 1995 & $1170-2600$ & $2.00-3.73$ & ND & ND & $59.4-65.5$ & Lee et al. (1998) \\
\hline Japan Sea/East Sea & $37-41^{\circ} \mathrm{N}, 129-134^{\circ} \mathrm{E}$ & 1993-1997 & $1002-3400$ & $0.98-2.74$ & ND & ND & $13-68$ & Hong et al. (1999) \\
\hline Mikata Five Lakes and Nyu Bay, Japan Sea & $35-36^{\circ} \mathrm{N}, 135-136^{\circ} \mathrm{E}$ & 1986-1988 & $11-40$ & $1.36-5.71$ & ND & ND & 109-347 & Yamamoto et al. (1990) \\
\hline Japan Sea & $37-46^{\circ} \mathrm{N}, 135-140^{\circ} \mathrm{E}$ & 1998 & $91-3670$ & $0.07-2.65$ & $0.160-0.223$ & $0.139-0.241$ & $5.7-241$ & Zheng and Yamada (2005) \\
\hline Japan Sea & $35-43^{\circ} \mathrm{N}, 130-135^{\circ} \mathrm{E}$ & 1994-1995 & $1512-3570$ & $0.011-1.79$ & ND & ND & ND & Pettersson et al. (1999) \\
\hline Japan Sea & $36-44^{\circ} \mathrm{N}, 131-139^{\circ} \mathrm{E}$ & $1997-2000$ & $359-3600$ & ND & ND & ND & $0.5-67.7$ & Ito et al. (2007) \\
\hline Japan Sea & $36-42^{\circ} \mathrm{N}, 131-133^{\circ} \mathrm{E}$ & 1998-2002 & $359-3560$ & $0.002-1.9$ & ND & ND & $4.7-37$ & Otosaka et al. (2006) \\
\hline Coast of the Korean Peninsula & $33-40^{\circ} \mathrm{N}, 125-130^{\circ} \mathrm{E}$ & 2000 & ND & $0.02-1.72$ & $0.15-0.23$ & $0.15-0.23$ & ND & Kim et al. (2003) \\
\hline Okhotsk Sea & $44-46^{\circ} \mathrm{N}, 145-146^{\circ} \mathrm{E}$ & 1998 & $1214-3053$ & $2.10-3.61$ & $0.170-0.204$ & $0.165-0.215$ & $81-271$ & Zheng and Yamada (2005) \\
\hline Okhotsk Sea & $51^{\circ} 00^{\prime} \mathrm{N}, 151^{\circ} 00^{\prime} \mathrm{E}$ & 1995 & 1300 & $0.92-1.12$ & ND & ND & 40 & Lee et al. (2003) \\
\hline Okhotsk Sea & $47-55^{\circ} \mathrm{N}, 140-151^{\circ} \mathrm{E}$ & 1995 & $136-1340$ & $0.30-0.77$ & ND & ND & ND & Pettersson et al. (1999) \\
\hline Off Japanese coast in the Pacific & $35-43^{\circ} \mathrm{N}, 141-146^{\circ} \mathrm{E}$ & 1998 & $2323-3318$ & $0.56-3.80$ & $0.140-0.242$ & $0.152-0.270$ & $62-74$ & Zheng and Yamada (2006b) \\
\hline Aomori Sea & $40-42^{\circ} \mathrm{N}, 141-142^{\circ} \mathrm{E}$ & $1991-2005$ & $50-1100$ & $0.485-4.00$ & $0.218-0.248$ & ND & ND & Oikawa et al. (2011) \\
\hline NW Pacific & $33-40^{\circ} \mathrm{N}, 155-163^{\circ} \mathrm{E}$ & 1995 & $2000-5500$ & $0.26-1.99$ & ND & ND & ND & Pettersson et al. (1999) \\
\hline
\end{tabular}

a: surface sediment 0-2 cm; ND: not determined.

Yamada, 2006b). However, for the western North Pacific, the inventory of ${ }^{239+240} \mathrm{Pu}$ ranged from 2.8 to $71.8 \mathrm{~Bq} \mathrm{~m}^{-2}$ (Moon et al., 2003). Thus the inventory of ${ }^{239+240} \mathrm{Pu}$ in the sediments cannot provide a direct index for source identification. Isotopic composition information should be combined with the inventory values to reach an accurate conclusion.

In summary, the ${ }^{239+240} \mathrm{Pu}$ activity and the ${ }^{240} \mathrm{Pu} /{ }^{239} \mathrm{Pu}$ atom ratio in the upper layer sediments $(<5 \mathrm{~cm})$ in the western North Pacific and its marginal seas off Japan before the FDNPP accident could be considered as lower than $5.81 \mathrm{mBqg}^{-1}$ and 0.28 , respectively. For the deeper layer sediments $(>5 \mathrm{~cm})$, the ${ }^{240} \mathrm{Pu} /{ }^{239} \mathrm{Pu}$ atom ratio could reach about 0.30 due to the earlier deposition of the PPG close-in fallout. The background values for ${ }^{241} \mathrm{Pu}$ activity and ${ }^{241} \mathrm{Pu} /{ }^{239+240} \mathrm{Pu}$ activity ratio in the sediments in the
Japanese coastal areas could be lower than $10 \mathrm{mBq} \mathrm{g}^{-1}$ and 3 , respectively. The inventories of Pu vary significantly depending on the different bottom topography and sedimentation dynamics.

\subsection{Vertical distributions of $\mathrm{Pu}$ in sediment cores from the western North Pacific after the FDNPP accident}

\subsubsection{Vertical distribution of Pu activities and Pu inventories}

The analytical results of $\mathrm{Pu}$ isotopes in the sediment core samples are summarized in Table 3 and plotted in Fig. 4. The surface ${ }^{239+240} \mathrm{Pu}$ activities in the sediments of ES4, MC1, MC5 and FS1 ranged from 0.476 to $2.809 \mathrm{mBq} \mathrm{g}^{-1}$. When 
Table 3. Results of $\mathrm{Pu}$ activities and $\mathrm{Pu}$ atom ratios in the sediment cores.

\begin{tabular}{|c|c|c|c|c|c|c|}
\hline $\begin{array}{r}\text { Sample interval } \\
(\mathrm{cm})\end{array}$ & $\begin{array}{r}\text { Ignition loss } \\
(\%)\end{array}$ & $\begin{array}{r}239+240 \mathrm{Pu} \text { activity } \\
\left(\mathrm{mBqg}^{-1}\right)\end{array}$ & $\begin{array}{r}{ }^{241} \mathrm{Pu} \text { activity } \\
\left(\mathrm{mBqg}^{-1}\right)\end{array}$ & $\begin{array}{r}{ }^{240} \mathrm{Pu} /{ }^{239} \mathrm{Pu} \\
\text { atom ratio }\end{array}$ & $\begin{array}{r}{ }^{241} \mathrm{Pu} /{ }^{239} \mathrm{Pu} \\
\text { atom ratio }\end{array}$ & $\begin{array}{r}239+240 \mathrm{Pu} \text { inventory } \\
\left(\mathrm{Bq} \mathrm{m}^{-2}\right)\end{array}$ \\
\hline \multicolumn{7}{|c|}{ KH 11-07 ES4 (375 $53.00^{\prime} \mathrm{N}, 143^{\circ} 35.00^{\prime} \mathrm{E}, 18 \mathrm{JUL} 2011,5400 \mathrm{~m}$ water depth, $22 \mathrm{~cm}$ core length) } \\
\hline $0-1^{\mathrm{a}}$ & 17.9 & $1.231 \pm 0.026$ & ND & $0.188 \pm 0.009$ & ND & 29.3 \\
\hline $1-2$ & 13.9 & $2.059 \pm 0.039$ & ND & $0.210 \pm 0.006$ & ND & $(0-8 \mathrm{~cm})$ \\
\hline $2-3$ & 13.1 & $2.795 \pm 0.052$ & ND & $0.203 \pm 0.006$ & ND & \\
\hline $3-4$ & 14.8 & $2.923 \pm 0.063$ & $7.42 \pm 0.61^{b}$ & $0.196 \pm 0.005$ & $0.0027 \pm 0.0002^{b}$ & \\
\hline $4-5$ & 12.4 & $1.025 \pm 0.042$ & ND & $0.212 \pm 0.004$ & ND & \\
\hline $5-6$ & 11.6 & $0.050 \pm 0.004$ & ND & $0.198 \pm 0.025$ & ND & \\
\hline $6-7$ & 11.1 & $0.007 \pm 0.002$ & ND & ND & ND & \\
\hline $7-8$ & 10.9 & $0.002 \pm 0.001$ & ND & ND & ND & \\
\hline
\end{tabular}

KH 11-07 FS1 $\left(37^{\circ} 20.00^{\prime} \mathrm{N}, 141^{\circ} 25.00^{\prime} \mathrm{E}, 2 \mathrm{Feb} 2011,150 \mathrm{~m}\right.$ water depth, $24 \mathrm{~cm}$ core length)

\begin{tabular}{|c|c|c|c|c|c|c|}
\hline $0-1^{\mathrm{a}}$ & 15.3 & $2.809 \pm 0.040$ & ND & $0.224 \pm 0.006$ & ND & 131.7 \\
\hline $1-2$ & 12.1 & $3.079 \pm 0.238$ & ND & $0.228 \pm 0.036$ & ND & $(0-20 \mathrm{~cm})$ \\
\hline $2-3$ & 10.1 & $2.494 \pm 0.261$ & ND & $0.233 \pm 0.011$ & ND & \\
\hline $3-4$ & 8.7 & $2.144 \pm 0.134$ & ND & $0.237 \pm 0.014$ & ND & \\
\hline $4-5$ & 8.0 & $1.970 \pm 0.109$ & ND & $0.232 \pm 0.023$ & ND & \\
\hline $5-6$ & 7.7 & $1.623 \pm 0.105$ & ND & $0.240 \pm 0.013$ & ND & \\
\hline $6-7$ & 8.2 & $1.663 \pm 0.053$ & ND & $0.228 \pm 0.010$ & ND & \\
\hline $7-8$ & 8.9 & $1.572 \pm 0.053$ & ND & $0.232 \pm 0.011$ & ND & \\
\hline $8-9$ & 9.0 & $1.361 \pm 0.050$ & ND & $0.236 \pm 0.012$ & ND & \\
\hline $9-10$ & 7.9 & $0.674 \pm 0.053$ & ND & $0.240 \pm 0.043$ & ND & \\
\hline $10-11$ & 8.1 & $0.466 \pm 0.032$ & ND & $0.243 \pm 0.028$ & ND & \\
\hline $11-12$ & 8.2 & $0.354 \pm 0.030$ & ND & $0.258 \pm 0.039$ & ND & \\
\hline $12-13$ & 8.4 & $0.473 \pm 0.030$ & ND & $0.275 \pm 0.037$ & ND & \\
\hline $13-14$ & 8.0 & $0.487 \pm 0.028$ & ND & $0.286 \pm 0.030$ & ND & \\
\hline $14-15$ & 7.7 & $0.042 \pm 0.005$ & ND & $0.262 \pm 0.051$ & ND & \\
\hline $15-16$ & 8.0 & $0.027 \pm 0.001$ & ND & ND & ND & \\
\hline $16-17$ & 8.1 & $0.009 \pm 0.002$ & ND & ND & ND & \\
\hline $17-18$ & 8.5 & $0.008 \pm 0.002$ & ND & ND & ND & \\
\hline $18-19$ & 8.2 & $0.007 \pm 0.001$ & ND & ND & ND & \\
\hline 19-20 & 8.3 & $0.005 \pm 0.002$ & ND & ND & ND & \\
\hline \multicolumn{7}{|c|}{ MR 11-05 MC5 $\left(37^{\circ} 35.01^{\prime} \mathrm{N}, 141^{\circ} 30.95^{\prime} \mathrm{E}, 19 \mathrm{Jul} 2011,141 \mathrm{~m}\right.$ water depth, $19 \mathrm{~cm}$ core length $)$} \\
\hline $0-1^{\mathrm{a}}$ & 3.9 & $0.476 \pm 0.008$ & ND & $0.255 \pm 0.009$ & ND & 95.5 \\
\hline $1-2$ & 4.1 & $0.486 \pm 0.015$ & ND & $0.243 \pm 0.015$ & ND & $(0-19 \mathrm{~cm})$ \\
\hline $2-3$ & 4.4 & $0.483 \pm 0.011$ & ND & $0.242 \pm 0.011$ & ND & \\
\hline $3-4$ & 4.5 & $0.504 \pm 0.014$ & ND & $0.242 \pm 0.014$ & ND & \\
\hline $4-5$ & 4.4 & $0.488 \pm 0.013$ & ND & $0.248 \pm 0.012$ & ND & \\
\hline $5-6$ & 4.1 & $0.469 \pm 0.016$ & ND & $0.244 \pm 0.015$ & ND & \\
\hline $6-7$ & 3.9 & $0.450 \pm 0.013$ & ND & $0.243 \pm 0.008$ & ND & \\
\hline $7-8$ & 4.7 & $0.459 \pm 0.011$ & ND & $0.237 \pm 0.013$ & ND & \\
\hline $8-9$ & 3.5 & $0.327 \pm 0.010$ & ND & $0.247 \pm 0.018$ & ND & \\
\hline $9-10$ & 3.6 & $0.286 \pm 0.008$ & ND & $0.241 \pm 0.014$ & ND & \\
\hline $10-11$ & 3.0 & $0.216 \pm 0.009$ & ND & $0.250 \pm 0.017$ & ND & \\
\hline $11-12$ & 3.1 & $0.135 \pm 0.005$ & ND & $0.247 \pm 0.016$ & ND & \\
\hline $12-13$ & 3.5 & $0.075 \pm 0.004$ & ND & $0.241 \pm 0.028$ & ND & \\
\hline $13-14$ & 4.2 & $0.092 \pm 0.004$ & ND & $0.236 \pm 0.026$ & ND & \\
\hline $14-15$ & 4.1 & $0.157 \pm 0.006$ & ND & $0.214 \pm 0.013$ & ND & \\
\hline $15-16$ & 4.1 & $0.216 \pm 0.009$ & ND & $0.201 \pm 0.017$ & ND & \\
\hline $16-17$ & 4.2 & $0.251 \pm 0.007$ & ND & $0.231 \pm 0.011$ & ND & \\
\hline $17-18$ & 4.3 & $0.225 \pm 0.007$ & ND & $0.237 \pm 0.016$ & ND & \\
\hline $18-19$ & 4.0 & $0.258 \pm 0.010$ & ND & $0.240 \pm 0.024$ & ND & \\
\hline
\end{tabular}


Table 3. Continued.

\begin{tabular}{|c|c|c|c|c|c|c|}
\hline $\begin{array}{r}\text { Sample interval } \\
(\mathrm{cm})\end{array}$ & $\begin{array}{l}\text { Ignition loss } \\
\text { content }(\%)\end{array}$ & $\begin{array}{r}239+240 \mathrm{Pu} \text { activity } \\
\left(\mathrm{mBq} \mathrm{g}^{-1}\right)\end{array}$ & $\begin{array}{r}{ }^{241} \mathrm{Pu} \text { activity } \\
\left(\mathrm{mBqg}^{-1}\right)\end{array}$ & $\begin{array}{r}{ }^{240} \mathrm{Pu} /{ }^{239} \mathrm{Pu} \\
\text { atom ratio }\end{array}$ & $\begin{array}{r}{ }^{241} \mathrm{Pu} /{ }^{239} \mathrm{Pu} \\
\text { atom ratio }\end{array}$ & $\begin{array}{r}239+240 \mathrm{Pu} \text { inventory } \\
\left(\mathrm{Bq} \mathrm{m}^{-2}\right)\end{array}$ \\
\hline \multicolumn{7}{|c|}{ MR 11-05 MC1 $\left(36^{\circ} 28.97^{\prime} \mathrm{N}, 141^{\circ} 29.93^{\prime} \mathrm{E}, 18 \mathrm{Jul} 2011,1327 \mathrm{~m}\right.$ water depth, $13 \mathrm{~cm}$ core length $)$} \\
\hline $0-1^{\mathrm{a}}$ & 7.8 & $1.580 \pm 0.026$ & ND & $0.236 \pm 0.007$ & ND & 32.6 \\
\hline $1-2$ & 8.4 & $1.372 \pm 0.023$ & ND & $0.241 \pm 0.010$ & ND & $(0-9 \mathrm{~cm})$ \\
\hline $2-3$ & 7.6 & $0.536 \pm 0.014$ & ND & $0.243 \pm 0.013$ & ND & \\
\hline $3-4$ & 8.8 & $0.159 \pm 0.018$ & ND & $0.241 \pm 0.042$ & ND & \\
\hline $4-5$ & 9.9 & $0.045 \pm 0.004$ & ND & $0.266 \pm 0.051$ & ND & \\
\hline $5-6$ & 8.5 & $0.016 \pm 0.003$ & ND & $0.293 \pm 0.080$ & ND & \\
\hline $6-7$ & 8.5 & $0.008 \pm 0.002$ & ND & ND & ND & \\
\hline $7-8$ & 9.6 & $0.006 \pm 0.001$ & ND & ND & ND & \\
\hline $8-9$ & 9.1 & $0.005 \pm 0.001$ & ND & ND & ND & \\
\hline \multicolumn{7}{|c|}{ MR 12-02 F1 ( $36^{\circ} 29.09^{\prime} \mathrm{N}, 141^{\circ} 30.01^{\prime} \mathrm{E}, 7 \mathrm{Jul} 2011,1322 \mathrm{~m}$ water depth, $13.2 \mathrm{~cm}$ core length) } \\
\hline $0-0.5$ & 8.7 & $1.774 \pm 0.054$ & ND & $0.240 \pm 0.006$ & ND & 77.2 \\
\hline $0.5-1$ & 9.5 & $1.910 \pm 0.024$ & ND & $0.238 \pm 0.004$ & ND & $(0-13.2 \mathrm{~cm})$ \\
\hline $1-1.5$ & 5.9 & $1.591 \pm 0.026$ & ND & $0.237 \pm 0.007$ & ND & \\
\hline $1.5-2$ & 5.9 & $1.441 \pm 0.032$ & ND & $0.241 \pm 0.008$ & ND & \\
\hline $2-3$ & 7.3 & $1.492 \pm 0.021$ & ND & $0.238 \pm 0.005$ & ND & \\
\hline $3-4$ & 7.6 & $1.462 \pm 0.021$ & ND & $0.235 \pm 0.006$ & ND & \\
\hline $4-5$ & 8.2 & $1.337 \pm 0.018$ & ND & $0.232 \pm 0.007$ & ND & \\
\hline $5-6$ & 7.0 & $0.774 \pm 0.014$ & ND & $0.234 \pm 0.009$ & ND & \\
\hline $6-7$ & 7.3 & $0.209 \pm 0.009$ & ND & $0.274 \pm 0.021$ & ND & \\
\hline $7-8$ & 7.3 & $0.264 \pm 0.013$ & ND & $0.290 \pm 0.029$ & ND & \\
\hline $8-9$ & 9.4 & $0.588 \pm 0.011$ & ND & $0.274 \pm 0.010$ & ND & \\
\hline $9-10$ & 7.5 & $0.219 \pm 0.008$ & ND & $0.284 \pm 0.023$ & ND & \\
\hline $10-12$ & 7.5 & $0.147 \pm 0.011$ & ND & $0.291 \pm 0.044$ & ND & \\
\hline $12-13.2$ & 6.8 & $0.364 \pm 0.012$ & ND & $0.256 \pm 0.019$ & ND & \\
\hline
\end{tabular}

a Data for 0-1 cm are cited from Zheng et al. (2012b); ${ }^{241} \mathrm{Pu}$ decay corrected to 15 October 2012; ND: not detected.

we compare them with the baseline data of the adjacent open oceans of the Pacific Ocean, there was no significant increase after the accident (Zheng et al., 2012b). For the F1 station, the surface ${ }^{239+240} \mathrm{Pu}$ activity was $1.774 \mathrm{mBq} \mathrm{g}^{-1}$, which was comparable to that $\left(1.580 \mathrm{mBq} \mathrm{g}^{-1}\right)$ of the $\mathrm{MC} 1$ station. The $\mathrm{F} 1$ station is close to the MC1 station and the F1 sampling date (7 July 2012) was one year after the MC1 sampling date (18 July 2011). The similar surface ${ }^{239+240} \mathrm{Pu}$ activity for these two stations indicated that there was no remarkable change for ${ }^{239+240} \mathrm{Pu}$ activity in the surface sediments in the western North Pacific about $110 \mathrm{~km}$ southeast of the FDNPP during the last year (July 2011 to July 2012). The highest ${ }^{239+240} \mathrm{Pu}$ activity $\left(3.079 \mathrm{mBq} \mathrm{g}^{-1}\right)$ was observed in the upper layer $(1-2 \mathrm{~cm})$ of FS1, which was lower than the upper limit of the baseline data $\left(5.38 \mathrm{mBq} \mathrm{g}^{-1}\right)$ before the FNDPP accident as we concluded in Sect. 3.1.

As shown in Fig. 4, the vertical profiles of ${ }^{239+240} \mathrm{Pu}$ activities in the five sediment cores showed different patterns. For the cores of MC1 and FS1, a surface ${ }^{239+240} \mathrm{Pu}$ maximum was observed and the ${ }^{239+240} \mathrm{Pu}$ activities decreased with core depth. For the cores of F1 and MC5, approximately uniform ${ }^{239+240} \mathrm{Pu}$ activities were found from the surface to a depth of $5 \mathrm{~cm}$ and $8 \mathrm{~cm}$, respectively. Similar observations were reported by Zheng et al. (2006b) for the ${ }^{239+240} \mathrm{Pu}$ distribution in two sediment cores (CM-03 and CM-04) from the western North Pacific (Fig. 4). Sediment particles mixing by bioturbation and/or physical factors after the deposition are thought to be the controllers of the surface mixing layer (SML) (Zheng et al., 2006b). For the marine environment near the Japanese coast, the M9.0 East Japan Earthquake was suggested to be another important factor that caused the displacement of the seafloor and resulted in turbulent diffusion of the seafloor sediments (Kawagucci et al., 2012). The SML depth $(8 \mathrm{~cm})$ in CM-04 was comparable with that of F1 and MC5. A subsurface maximum of ${ }^{239+240} \mathrm{Pu}$ activity was found in the sediment core of ES4. Usually, in areas with a high sedimentation rate, the subsurface maximum has corresponded to the year 1963, when the largest global fallout of Pu occurred (Hong et al., 1999). Moon et al. (2003) reported relatively low sedimentation rates $(0.12-$ $\left.0.35 \mathrm{~cm} \mathrm{ky}^{-1}\right)$ in the western North Pacific after they investigated the ${ }^{14} \mathrm{C}$ and ${ }^{230} \mathrm{Th}_{\mathrm{ex}}$ distributions in the sediment profiles. As the water depth exceeds $5000 \mathrm{~m}$ at the ES4 station, the sedimentation rate is not a key factor controlling 
$\rightarrow{ }^{239+240} \mathrm{Pu}$ activity $\left(\mathrm{mBq} \mathrm{g}^{-1}\right)$

$\rightarrow-240 \mathrm{Pu} /{ }^{239} \mathrm{Pu}$ atom ratio
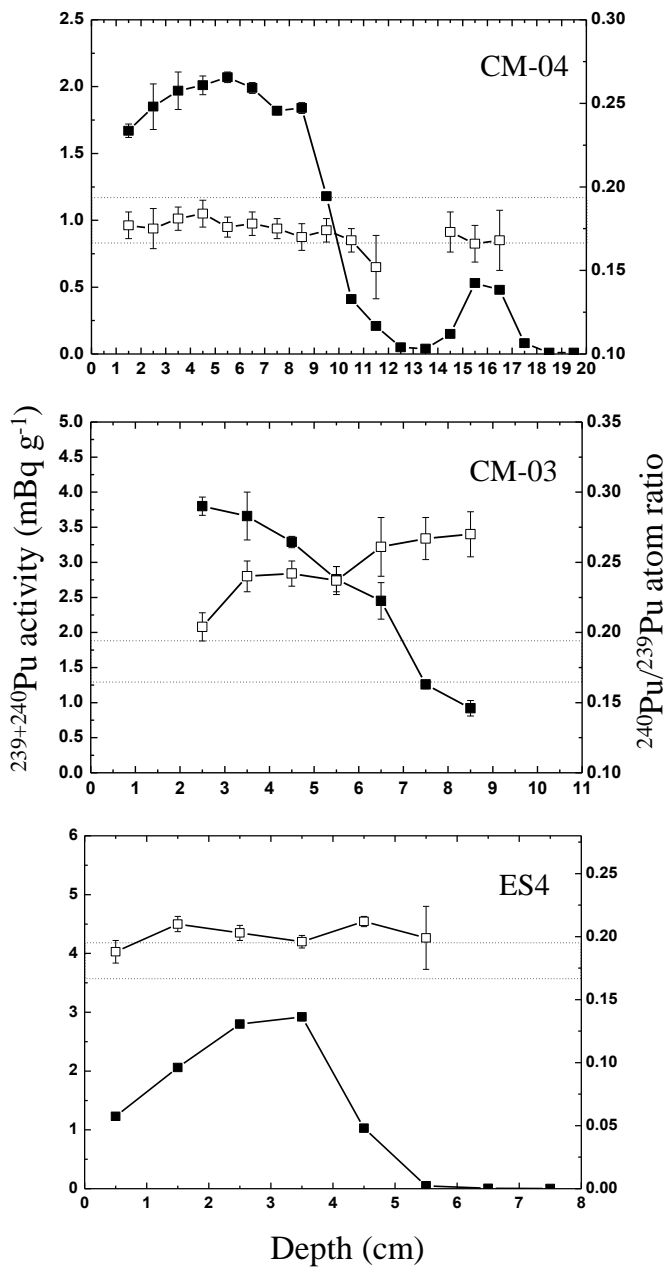
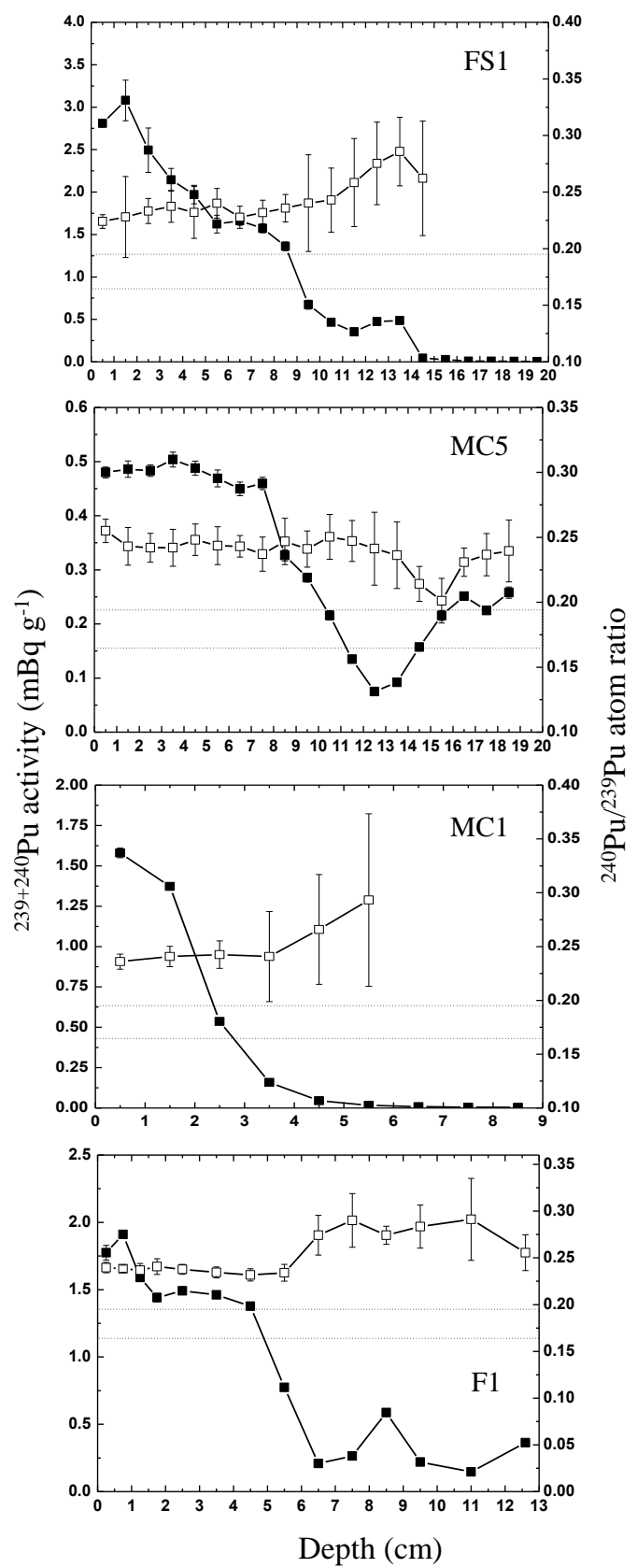

Fig. 4. Vertical profiles of ${ }^{239+240} \mathrm{Pu}$ activities and ${ }^{240} \mathrm{Pu} /{ }^{239} \mathrm{Pu}$ atom ratios in the sediment cores. The dashed lines indicate the ${ }^{240} \mathrm{Pu} /{ }^{239} \mathrm{Pu}$ atom ratio range of global fallout (0.180 \pm 0.014$)$. CM-03 and CM-04 are from Zheng and Yamada (2006b).

the vertical distribution of Pu isotopes there. However, the biological activity in the seafloor in the western North Pacific is high, evidencing a high bioturbation rate in the surficial marine sediment (Harada and Shibamoto, 2002). The penetration depth of radionuclides into the seabed can be measured and then related to mixing rate and sedimentation rate by incorporating the dispersion-advection equation (Demaster et al., 1985):

$Z=\sqrt{2 D_{b} T}+S T$, where $Z$ is the penetration depth $(\mathrm{cm}), D_{b}$ is the mixing coefficient $\left(\mathrm{cm}^{2} \mathrm{yr}^{-1}\right), T$ is the elapsed time (yr) since deposition and $S$ is the sedimentation rate $\left(\mathrm{cm} \mathrm{yr}^{-1}\right)$. The particle mixing coefficient ranges from 0.02 to $1.00 \mathrm{~cm}^{2} / \mathrm{y}$ in the western North Pacific (Moon et al., 2003). If we assume that $48 \mathrm{yr}$ have passed since 1963, the penetration depth of $\mathrm{Pu}$ in the western North Pacific can be roughly estimated to be $1.4-9.9 \mathrm{~cm}$ by Eq. (1). This is consistent with the result $(8 \mathrm{~cm})$ we observed at the ES4 station. Similarly, Harada and Shibamoto (2002) observed that the penetration depth 
of excess ${ }^{210} \mathrm{~Pb}$ was $7.2 \mathrm{~cm}$ in the same sea area of ES4. The vertical profiles of ${ }^{239+240} \mathrm{Pu}$ activity and ignition loss in the sediment core samples are shown in Fig. 1S (see Supplement). No general relationships between Pu concentration and ignition loss were found from our results.

High ${ }^{241} \mathrm{Pu}$ activities $\left(4.5-34.8 \mathrm{mBq} \mathrm{g}^{-1}\right)$ and ${ }^{241} \mathrm{Pu} /{ }^{239+240} \mathrm{Pu}$ activity ratio (107.8) in the surface soil and litter samples from the $20-30 \mathrm{~km}$ zone around the FNDPP were observed, evidencing the contamination from the accident (Zheng et al., 2012b). However, for the five sediment cores investigated in this study, a detectable ${ }^{241} \mathrm{Pu}$ activity $\left(7.42 \mathrm{mBq} \mathrm{g}^{-1}\right)$ only occurred at the ES4 station at a depth of $3-4 \mathrm{~cm}$ where the ${ }^{239+240} \mathrm{Pu}$ activity peaked. This value was typically in the range $\left(<10 \mathrm{mBq} \mathrm{g}^{-1}\right)$ of the background database before the FNDPP accident. Meanwhile, the ${ }^{241} \mathrm{Pu} /{ }^{239+240} \mathrm{Pu}$ activity ratio (2.5), comparable with reported results before the accident, was significantly lower than that derived from the FDNPP accident.

Plutonium inventory in sediment columns reflects the source function, transport of $\mathrm{Pu}$ in water and on particles, and the mixing process; thus it is an important parameter for geochemical study of $\mathrm{Pu}$. The inventory of $\mathrm{Pu}$ in a sediment core can be estimated by summing the $\mathrm{Pu}$ concentration in each layer of the sediment (Livingston et al., 2001):

$I_{\mathrm{S}}=\sum_{i=1}^{M} S_{i} D_{i}\left(U_{i}-L_{i}\right)$

where $I_{\mathrm{S}}$ is the Pu inventory in a sediment column $\left(\mathrm{Bq} \mathrm{m}^{-2}\right)$, $\mathrm{M}$ is the number of sediment layers (the layer number is counted downward from the surface to the deeper layer), $S_{i}$ is the $\mathrm{Pu}$ concentration in layer $i\left(\mathrm{~Bq} \mathrm{~kg}^{-1}\right.$, dry weight $), D_{i}$ is the dry bulk density of layer $i\left(\mathrm{~kg} \mathrm{~m}^{-3}\right), U_{i}$ is the upper boundary of layer $i(\mathrm{~m})$ and $L_{i}$ is the lower boundary of layer $i(\mathrm{~m})$.

The obtained Pu inventories for ES4, FS1, MC5, MC1 and F1 were 29.3, 131.7, 95.5, 32.6 and $77.2 \mathrm{~Bq} \mathrm{~m}^{-2}$, respectively. As shown in Fig. 5, the inventories varied significantly. The lowest inventory was observed at ES4 station and the relatively low Pu accumulation may be due to the deep water depth and the low sedimentation rate (Bu et al., 2012). The highest inventory was found at the FS1 station, which was the nearest one to the Fukushima coast among the five sampling stations. High Pu inventories seem to be a common phenomenon in the coastal sediments in the western North Pacific and its marginal seas. For example, Lee et al. (2004) observed extremely high $\mathrm{Pu}$ inventories (201-693 $\mathrm{Bq} \mathrm{m}^{-2}$ ) in the Southern Okinawa Trough. Zheng et al. (2005, 2006a) reported that the $\mathrm{Pu}$ inventories in the Japan Sea and the Okhotsk Sea ranged from 5.7 to $241 \mathrm{~Bq} \mathrm{~m}^{-2}$ and from 81 to $271 \mathrm{~Bq} \mathrm{~m}^{-2}$, respectively. The advective westward transport of Pu from the Marshall Islands by the North Equatorial Current followed by northward transport of Kuroshio Current was suggested to be an important factor causing the high $\mathrm{Pu}$ input (Lee et al., 2004; Zheng et al., 2004, 2006c). The Pu

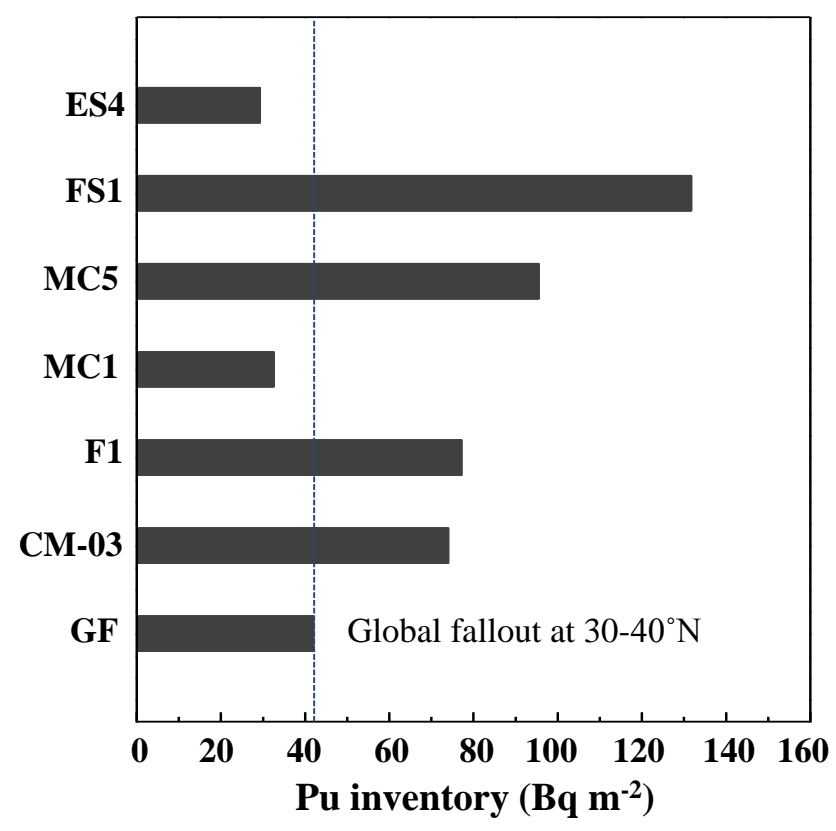

Fig. 5. $\mathrm{Pu}$ inventories in the sediment cores. The $\mathrm{Pu}$ inventory of CM-03 (0-10 cm) was cited from Zheng and Yamada (2006b). The global fallout $\mathrm{Pu}$ inventory at $30-40^{\circ} \mathrm{N}$ was from UNSCEAR (1993).

inventory $\left(77.2 \mathrm{~Bq} \mathrm{~m}^{-2}\right)$ at the $\mathrm{F} 1$ station is more than two times that $\left(32.6 \mathrm{~Bq} \mathrm{~m}^{-2}\right)$ at the $\mathrm{MC} 1$ station. These two stations are off the Ibaraki coast and are very close geographically. In the coastal area of Ibaraki, Otosaka et al. (2012) investigated the distribution of radiocesium in the sediments collected from near-coast to off-coast sites over some time after the FDNPP accident; and they found that the radiocesium, first appeared in the near-coast region, and then was transported to the off-coast region through suspended fine particles in a high-turbidity layer. However, the Pu inventory variation between the $\mathrm{F} 1$ and $\mathrm{MC} 1$ stations could not be simply explained as $\mathrm{Pu}$ accumulation from the near-coast region during the last year (July 2011 to July 2012). A more comprehensive comparison can be done with the results of the CM-03 station. The CM-03 station, which is located $200 \mathrm{~km}$ southeast of the FDNPP, is the only area close to the FNDPP for which the vertical distribution of ${ }^{239+240} \mathrm{Pu}$ activity before the accident is known. In the CM-03 sediment core, the $\mathrm{Pu}$ inventory was reported to be $74 \mathrm{~Bq} \mathrm{~m}^{-2}$ (Zheng and Yamada, 2006b), which was comparable with the result of F1.

\subsubsection{Vertical distribution of $\mathrm{Pu}$ atom ratios and the possible sources of $\mathrm{Pu}$}

$\mathrm{Pu}$ atom ratios $\left({ }^{240} \mathrm{Pu} /{ }^{239} \mathrm{Pu}\right.$ and $\left.{ }^{241} \mathrm{Pu} /{ }^{239} \mathrm{Pu}\right)$ have been demonstrated to be good indicators for the Pu source identification. For instance, the atom ratio of ${ }^{240} \mathrm{Pu} /{ }^{239} \mathrm{Pu}$ in weapon grade $\mathrm{Pu}$ is typically around 0.05 and higher ratios can be expected with higher neutron fluxes associated with an increase 


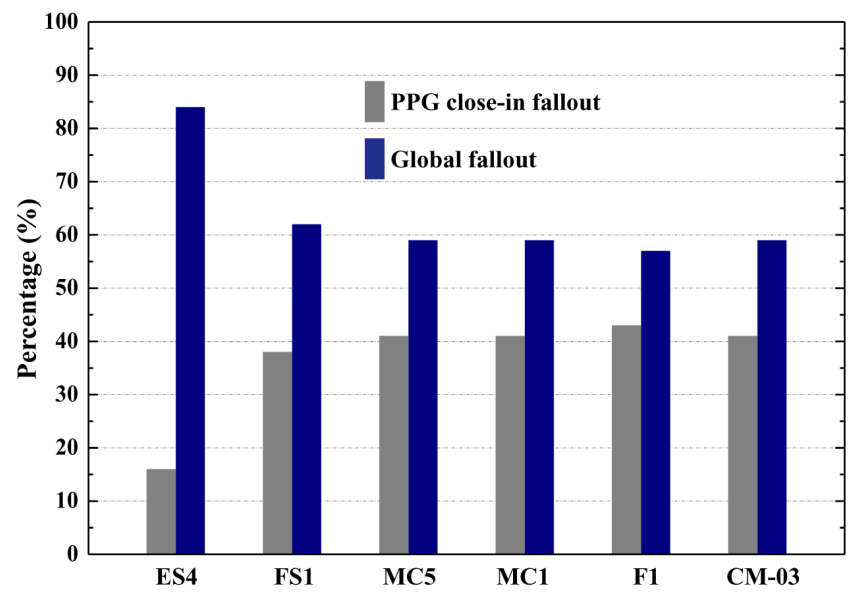

Fig. 6. The percentage of $\mathrm{Pu}$ that originated from global fallout and PPG close-in fallout in the sediment cores. The data for CM-03 were calculated from Zheng and Yamada (2006b).

in the yield of a nuclear detonation (Buesseler, 1997; Koide, et al., 1985). For a nuclear reactor, the $\mathrm{Pu}$ atom ratios can vary from 0.23 to 0.65 depending on the fuel characteristics, type and design of the reactor, operational conditions of the plant and cooling time since the fuel was last irradiated in the reactor (Ketterer and Szechenyi, 2008; Schwantes et al., 2012; Taylor et al., 2001). The ${ }^{240} \mathrm{Pu} /{ }^{239} \mathrm{Pu}$ and ${ }^{241} \mathrm{Pu} /{ }^{239} \mathrm{Pu}$ atom ratio fingerprints for the $\mathrm{Pu}$ isotopes released from the FDNPP accident were suggested to be $0.303-0.330$ and $0.103-0.135$, respectively, and they were significantly higher than the global fallout values (Zheng et al., 2012b).

As shown in Table 3 and Fig. 4 , the ${ }^{240} \mathrm{Pu} /{ }^{239} \mathrm{Pu}$ atom ratios in the five core samples have four major characteristics: (1) the ratios ranged from 0.188 to 0.293 and were typically higher than the reported global fallout value (0.18); (2) all the cores showed a nearly uniform distribution of ${ }^{240} \mathrm{Pu} /{ }^{239} \mathrm{Pu}$ atom ratio in the upper sediment layers; (3) the ${ }^{240} \mathrm{Pu} /{ }^{239} \mathrm{Pu}$ atom ratios increased from a definite depth in the cores of $\mathrm{MC1}$, F1 and FS1, while the ratios stayed almost uniform in the cores of MC5 and ES4; and (4) the inventory-weighted ${ }^{240} \mathrm{Pu} /{ }^{239} \mathrm{Pu}$ atom ratio $(0.202)$ at the ES4 station was lower than the ratios of the other four stations (FS1, 0.236; MC5, 0.240; MC1, 0.240; F1, 0.243).

We can see that almost all the sediment samples investigated in this study showed higher ${ }^{240} \mathrm{Pu} /{ }^{239} \mathrm{Pu}$ atom ratio than the global fallout. However, a higher ${ }^{240} \mathrm{Pu} /{ }^{239} \mathrm{Pu}$ atom ratio was observed in a wide range of sea areas in the western North Pacific before the FNDPP accident due to the presence of the PPG close-in fallout as discussed in Sect. 3.1. As the majority of the tests at the PPG were conducted at or just above the earth's surface and the maximum deposition occurred in 1954, the injection of Pu from the PPG as tropospheric deposition to the western North Pacific happened before the global fallout injection. Therefore, the higher ${ }^{240} \mathrm{Pu} /{ }^{239} \mathrm{Pu}$ atom ratios in the deeper layers in the sediment cores of MC1, F1 and FS1 retained their validity as a record for the PPG close-in fallout. In Sagami Bay, on the western North Pacific margin, a similar distribution for the ${ }^{240} \mathrm{Pu} /{ }^{239} \mathrm{Pu}$ atom ratio in the sediment core was also observed (Zheng and Yamada, 2004); that is, a nearly uniform ${ }^{240} \mathrm{Pu} /{ }^{239} \mathrm{Pu}$ atom ratio of about 0.24 distributed from the surface down to the layer $12-14 \mathrm{~cm}$ deep, and a ratio higher than 0.27 starting from the layer at $16-18 \mathrm{~cm}$ depth. Our observed results provided further evidence for the hypothesis that the oceanic processes (North Equatorial Current and the Kuroshio Current) transported the PPG close-in fallout $\mathrm{Pu}$ westwards as far as the Japanese coast. The uniform distribution of the ${ }^{240} \mathrm{Pu} /{ }^{239} \mathrm{Pu}$ atom ratio in the sediment cores of MC5 and ES4 could be due to the mixing process caused by bioturbation and/or physical factors. Unlike the other four stations, the ES4 station is located in the pathway of the southward flowing Oyashio Current, which carries water bearing global fallout Pu. The CM-04 station is located in northern Japan in the western North Pacific and is affected by the Oyashio Current as well, and it showed a typical distribution of ${ }^{240} \mathrm{Pu} /{ }^{239} \mathrm{Pu}$ atom ratios which was the same as the global fallout. Thus the trace of PPG-derived Pu at the ES4 station could be from direct fallout in that region when the nuclear weapon tests were conducted.

We have concluded in Sect. 3.1 that the ${ }^{240} \mathrm{Pu} /{ }^{239} \mathrm{Pu}$ atom ratio in the western North Pacific was typically below 0.28 in the upper layer $(<5 \mathrm{~cm})$ sediments before the FDNPP accident. For all the sediment cores investigated in this study, the upper layer sediment ${ }^{240} \mathrm{Pu} /{ }^{239} \mathrm{Pu}$ atom ratio was below the background baseline limit. The deeper layer sediments, characterized by high ${ }^{240} \mathrm{Pu} /{ }^{239} \mathrm{Pu}$ atom ratio in $\mathrm{FS} 1, \mathrm{MC} 1$ and F1 were due to the early deposition of the PPG close-in fallout. Thus no significant amounts of Pu injection from the FDNPP accident, which has a high ${ }^{240} \mathrm{Pu} /{ }^{239} \mathrm{Pu}$ atom ratio $(>0.30)$, were observed in the investigated regions. The data on the distribution of ${ }^{241} \mathrm{Pu}$ give further support to this conclusion. No ${ }^{241} \mathrm{Pu}$ was detected for all the samples except one at the ES4 station with a concentration of $7.42 \mathrm{mBq} \mathrm{g}^{-1}$ and a ${ }^{241} \mathrm{Pu} /{ }^{239} \mathrm{Pu}$ atom ratio of 0.0029 . This ${ }^{241} \mathrm{Pu} /{ }^{239} \mathrm{Pu}$ atom ratio was similar to the result $(0.0033)$ we observed in the sediment at ES2 (Zheng et al., 2012a) and results (0.00310.0033 ) in the sediment near the Bikini Atoll reported by Lee et al. (2005). As the Fukushima-derived ${ }^{241} \mathrm{Pu} /{ }^{239} \mathrm{Pu}$ atom ratio was much higher than the observed result, the presence of ${ }^{241} \mathrm{Pu}$ in ES4 further evidenced the PPG source contribution to that region.

Presuming that the ${ }^{240} \mathrm{Pu} /{ }^{239} \mathrm{Pu}$ atom ratio for global fallout is 0.18 (Kelly et al., 1999), and that the representative ${ }^{240} \mathrm{Pu} /{ }^{239} \mathrm{Pu}$ atom ratio for the PPG close-in fallout is 0.36 (Buesseler, 1999; Diamond et al., 1960; Muramatsu et al., 2001), we could estimate the contribution of Pu source to the $\mathrm{Pu}$ inventory in the western North Pacific by using a two-end 
member-mixing model (Krey et al., 1976):

$Y=\frac{(\mathrm{Pu})_{P}}{(\mathrm{Pu})_{G}}=\frac{\left(R_{G}-R_{S}\right)\left(1+3.66 R_{P}\right)}{\left(R_{S}-R_{P}\right)\left(1+3.66 R_{G}\right)}$,

where $(\mathrm{Pu})$ is the ${ }^{239+240} \mathrm{Pu}$ activity; $R$ is the ${ }^{240} \mathrm{Pu} /{ }^{239} \mathrm{Pu}$ atom ratio; and the subscript $P, G$ and $S$ refer to PPG closein fallout, global fallout and measured sediment samples, respectively. Via Eq. (3), we calculated the inventory-weighted percentages of the PPG close-in fallout in each sediment core.

As shown in Fig. 6, we found that the PPG close-in fallout contributed a nearly constant percentage (ca. $40 \%$ ) of the $\mathrm{Pu}$ inventory in the sediment cores in the western North Pacific off the eastern coast of Japan except for ES4. As discussed above, ES4 is located in the pathway of the Oyashio Current, and received only a trace of directly deposited Pu from the PPG close-in fallout. For stations F1 and MC1, although the $\mathrm{Pu}$ inventories in these two close stations showed significant variation, the sources of Pu in them were identical (the PPG close-in fallout $\mathrm{Pu}$ and global fallout $\mathrm{Pu}$ ), suggesting no detectable Pu contamination originating from the FDNPP accident injected to that region during the year since the accident.

\section{Conclusions}

The vertical profiles of $\mathrm{Pu}$ isotopes in five sediments cores obtained in the western North Pacific from July 2011 to July 2012 after the FNDPP accident as well as surface sediments in seven Japanese estuaries collected before the FNDPP accident were investigated. We first established the comprehensive background baseline data for the Pu distribution in the sediments in the western North Pacific and its marginal seas before the FNDPP accident. Then we compared the results of the five sediment cores with the baseline data. We could not identify any extra Pu injection from the FDNPP accident in the marine sediments collected outside the $30 \mathrm{~km}$ zone from the plant site up to the time of sampling (July 2012). The global fallout and the PPG close-in fallout $\mathrm{Pu}$ were the two main sources for the Pu contamination in the marine environment outside the $30 \mathrm{~km}$ zone. It has been modeled recently that if any $\mathrm{Pu}$ contamination from the FDNPP accident occurred in the sea, it would remain in a very close area around the power plant because of the low mobility of plutonium isotopes in the marine environment (Perianez et al., 2013). The Pu contamination situation in the marine environment within the $30 \mathrm{~km}$ zone around the FDNPP needs further investigation before a more comprehensive conclusion can be reached.

\section{Supplementary material related to this article is available online at: http://www.biogeosciences.net/10/ 2497/2013/bg-10-2497-2013-supplement.pdf.}

Acknowledgements. We would like to thank the Chief Scientist and the scientific party of KH 11-07, MR 11-05 and MR 12-02 cruises and the captain, officers and crew of the R/V Hakuho-maru and Mirai for their help in the sediment sampling. This work was supported by MEXT Kakenhi Grant in Aid for Scientific Research on Innovative Areas (24110004), and partly supported by the Agency for Natural Resources and Energy, the Ministry of Economy, Trade and Industry (METI), Japan. W. T. Bu thanks the China Scholarship Council for a scholarship (201206010102) for his $\mathrm{Ph}$. D study. We are grateful for comments and suggestions from two anonymous reviewers and the handling editor $\mathrm{H}$. Nies.

Edited by: H. Nies

\section{References}

Aoyama, M., Tsumune, D., and Hamajima, Y.: Distribution of ${ }^{137} \mathrm{Cs}$ and ${ }^{134} \mathrm{Cs}$ in the North Pacific Ocean: impacts of the TEPCO Fukushima-Daiichi NPP accident, J. Radioanal. Nucl. Chem., 296, 535-539, 2013.

Bailly du Bois, P., Laguionie, P., Boust, D., Korsakissok, I., Didier, D., and Fiévet, B.: Estimation of marine source-term following Fukushima Dai-ichi accident, J. Environ. Radioact., 114, 2-9, 2012.

Bowen, V. T., Noshkin, V. E., Livingston, H. D., and Volchok, H. L.: Fallout radionuclides in the Pacific Ocean: vertical and horizontal distributions, largely from geosecs stations, Earth Planet. Sci. Lett., 49, 411-434, 1980.

Bu, W. T., Zheng, J., Aono, T., Tagami, K., Uchida, S., Zhang, J., Guo, Q. J., and Yamada M.: Investigating plutonium contamination in marine sediments off Fukushima following the Fukushima Dai-ichi Nuclear Power Plant accident, In proceedings of the Environmental monitoring and dose estimation of residents after accident of TEPCO's Fukushima Daiichi Nuclear Power Stations, Edited by KUR Research Reactor Institute, Kyoto University, Japan, 141-145, 2012.

Buesseler, K. O.: The isotopic signature of fallout plutonium in the North Pacific, J. Environ. Radioact., 36, 69-83, 1997.

Buesseler, K. O.: Fishing for answers off Fukushima, Science, 338, 480-482, 2012.

Buesseler, K. O., Aoyama, M., and Fukasawa, M.: Impacts of the Fukushima nuclear power plants on marine radioactivity, Environ. Sci. Technol., 45, 9931-9935, 2011.

Buesseler, K. O., Jayne, S. R., Fisher, N. S., Rypina I. I., Baumann, H., Baumann, Z., Breier, C. F., Douglass, E. M., George, J., Macdonald, A. M., Miyamoto, H., Nishikawa, J., Pike, S. M., and Yoshida, S.: Fukushima-derived radionuclides in the ocean and biota off Japan, Proc. Natl. Acad. Sci., 109, 5984-5988, 2012.

Burns, P. C., Ewing, R. C., and Navrotsky, A.: Nuclear fuel in a reactor accident, Science, 335, 1184-1188, 2012.

Chino, M., Nakayama, H., Nagai, H., Terada, H., Katata, G., and Yamazawa, H.: Preliminary estimation of release amounts of ${ }^{131} \mathrm{I}$ and ${ }^{137} \mathrm{Cs}$ accidentally discharged from the Fukushima Daiichi Nuclear Power Plant into the atmosphere, J. Nucl. Sci. Technol., 48, 1129-1134, 2011.

Demaster, D. J., Mckee, B. A., Nittrouer, C. A., Qian, J. C., and Cheng, G. D.: Rates of sediment accumulation and particle reworking based on radiochemical measurements from continental 
shelf deposits in the East China Sea, Cont. Shelf Res., 4, 143$158,1985$.

Diamond, H., Fields, P. R., Stevens, C. S., Studier, M. H., Fried, S. M., Inghram, M.G., Hess, D. C., Pyle, G. L., Mech, J. F., Manning, W. M., Ghiorso, A., Thompson, S. G., Higgins, G. H., Seaborg, G. T., Browne, C. I., Smith, H. L., and Spence, R. W.: Heavy isotope abundances in "Mike" thermonuclear device, Phys. Rev. 119, 2000-2004, 1960.

Dong, W., Zheng, J., Guo, Q. J., Yamada, M., and Pan, S. M.: Characterization of plutonium in deep-sea sediments of the Sulu and South China Seas, J. Environ. Radioact., 101, 622-629, 2010.

Fowler, S. W., Ballestra, S., Rosa, J. L., and Fukai, R.: Vertical transport of particulate-associated plutonium and americium in the upper water column of the Northeast Pacific, Deep-Sea Res., 30, 1221-1233, 1983.

Harada, K. and Shibamoto, Y.: Excess ${ }^{210} \mathrm{~Pb}$ in the sediment and benthic biological activity in the western North Pacific, Proceedings of The Twelfth International Offshore and Polar Engineering Conference, Kitakyushu, Japan, 407-412, 2002.

Honda, M. C., Aono, T., Aoyama, M., Hamajima, Y., Kawakami, H., Kitamura, M., Masumoto, Y., Miyazawa, Y., Takigawa, M., and Saino, T.: Dispersion of artificial caesium-134 and -137 in the western North Pacific one month after the Fukushima accident, Geochem. J., 46, e1-e9, 2012.

Honda, M. C., Kawakami, H., Watanabe, S., and Saino, T.: Fukushima-derived radiocesium in western North $\mathrm{Pa}$ cific sediment traps, Biogeosciences Discuss., 10, 2455-2477, doi:10.5194/bgd-10-2455-2013, 2013.

Hong, G. H., Lee, S. H., Kim, S. H., Chung, C. S., and Baskaran, M.: Sedimentary fluxes of ${ }^{90} \mathrm{Sr},{ }^{137} \mathrm{Cs},{ }^{239,240} \mathrm{Pu}$ and ${ }^{210} \mathrm{~Pb}$ in the East Sea (Sea of Japan), Sci. Total Environ., 237/238, 225240, 1999.

IAEA: Sediment distribution coefficients and concentration factors for biota in the marine environment, in: Technical Reports series 422, International Atomic Energy Agency, Austria, Vienna, 1012, 2004.

Imanaka, T., Endo, S., Sugai, M., Ozawa, S., Shizuma, K., and Yamamoto, M.: Early radiation survey of Iitate Village, which was heavily contaminated by the Fukushima Daiichi accident, conducted on 28 and 29 March 2011, Health Phys., 102, 680-686, 2012.

Inoue, M., Kofuji, H., Nagao, S., Yamamoto, M., Hamajima, Y., Yoshida, K., Fujimoto, K., Takada, T., and Isoda, Y.: Lateral variation of ${ }^{134} \mathrm{Cs}$ and ${ }^{137} \mathrm{Cs}$ concentrations in surface seawater in and around the Japan sea after the Fukushima Dai-ichi Nuclear Power Plant accident, J. Environ. Radioact., 109, 45-51, 2012.

Ito, T., Otosaka, S., and Kawamura, H.: Estimation of total amounts of anthropogenic radionuclides in the Japan Sea, J. Nucl. Sci. Technol., 44, 912-922, 2007.

Kawagucci, S., Yoshida, Y. T., Noguchi, T., Honda, M. C., Uchida, H., Ishibashi, H., Nakagawa, F., Tsunogai, U, Okamura, K., Takaki, Y., Nunoura T., Miyazaki, J., Hirai, C. M., Lin, W., Kitazato, H., and Takai, K.: Disturbance of deep-sea environments induced by the M9.0 Tohoku Earthquake, Sci. Rep., 2, 1-7, doi:10.1038/srep00270, 2012.

Kelley, J. M., Bond, L. A., and Beasley, T. M.: Global distribution of Pu isotopes and ${ }^{237} \mathrm{~Np}$, Sci. Total Environ., 237/238, 483-500, 1999.
Ketterer, M. E. and Szechenyi, S. C.: Determination of plutonium and other transuranic elements by inductively coupled plasma mass spectrometry: A historic perspective and new frontiers in the environmental sciences, Spectrochim. Acta B, 63, 719-737, 2008.

Kim, C. K., Kim, C. S., Chang, B. U., Choi, S. W., Chung, C. S., Hong, G. H., Hirose, K., and Pettersson H. B. L.: ${ }^{240} \mathrm{Pu} /{ }^{239} \mathrm{Pu}$ atom ratios in the bottom sediments of the NW Pacific Ocean, J. Radioanal. Nucl. Chem., 258, 265-268, 2003.

Koide, M., Bertine, K. K., Chow, T. J., and Goldberg, E. D.: The ${ }^{240} \mathrm{Pu} /{ }^{239} \mathrm{Pu}$ ratio, a potential geochronometer, Earth Planet. Sci. Lett., 72, 1-8, 1985.

Krey, P. W., Hardy, E. P., Pachucki, C., Rourke, F., Coluzza, J., and Benson, W. K.: Mass isotopic composition of global fallout plutonium in soil, Proceeding of a symposium of transuranium nuclides in the environment, IAEA-SM-199-39, 671-678, 1976.

Kusakabe, M., Ku, T. L., Harada, K., Taguchi, K., and Tsunogai, S.: Chernobyl radioactivity found in mid-water sediment interceptors in the N Pacific and Bering Sea, Geophys. Res. Lett., 15, 44-47, 1988.

Lee, M. H., Lee, C. W., Moon, D. S., Kim, K. H., and Boo, B. H.: Distribution and inventory of fallout $\mathrm{Pu}$ and $\mathrm{Cs}$ in the sediment of the East Sea of Korea, J. Environ. Radioact., 41, 99-110, 1998.

Lee, S. H., Gastaud, J., Povinec, P. P., Hong, G. H., Kim, S. H., Chung, C. S., Lee, K. W., and Pettersson, H. B. L.: Distribution of plutonium and americium in the marginal seas of the northwest Pacific Ocean, Deep-Sea Res. II, 50, 2727-2750, 2003.

Lee, S. H., Povinec, P. P., Wyse, E., Pham, M. K., Hong, G. H., Chung, C. S., Kim, S. H., and Lee, H. J.: Distribution and inventories of ${ }^{90} \mathrm{Sr},{ }^{137} \mathrm{Cs},{ }^{241} \mathrm{Am}$ and $\mathrm{Pu}$ isotopes in sediments of the Northwest Pacific Ocean, Mar. Geol., 216, 249-263, 2005.

Lee, S. Y., Huh, C. A., Su, C. C., and You, C. F.: Sedimentation in the Southern Okinawa Trough: enhanced particle scavenging and teleconnection between the Equatorial Pacific and western Pacific margins, Deep-Sea Res. I, 51, 1769-1780, 2004.

Liao, H. Q., Zheng, J., Wu, F. C., Yamada, M., Tan, M. G., and Chen, J. M., Determination of plutonium isotopes in freshwater lake sediments by sector-field ICP-MS after separation using ionexchange chromatography, Appl. Radiat. Isot., 66, 1138-1145, 2008.

Lindahl, P., Asami, R., Iryu, Y., Worsfold, P., Keith-Roach, M., and Choi, M. S.: Sources of plutonium to the tropical Northwest Pacific Ocean (1943-1999) identified using a natural coral archive, Geochim. Cosmochim. Acta., 75, 1346-1356, 2011.

Liu, Z. Y., Zheng, J., Pan, S. M., Dong, W., Yamada, M., Aono, T., and Guo, Q. J.: Pu and ${ }^{137} \mathrm{Cs}$ in the Yangtze River Estuary sediments: distribution and source identification, Environ. Sci. Technol., 45, 1805-1811, $2011 \mathrm{a}$.

Liu, Z. Y., Zheng, J., Yamada, M., Pan, S. M., and Kawahata, H.: Plutonium characteristics in sediments of Hiroshima Bay in Seto Inland Sea in Japan, J. Radioanal. Nucl. Chem., 288, 911-917, 2011 b.

Livingston, H. D., Povinec, P. P., Ito, T., and Togawa, O.: The behaviour of plutonium in the Pacific Ocean, in: Plutonium in the Environment, edited by: Kudo, A., Elsevier Science Ltd, Oxford, UK, 267-292, 2001.

MEXT: Environmental Radiation Database, www.kankyo-hoshano. go.jp/08/ers_lib/ers_abs53.pdf, 2008. 
Moon, D. S., Hong, G. H., Kim, Y. I., Baskaran, M., Chung, C. S., Kim, S. H., Lee, H. J., Lee, S. H., and Povinec, P. P.: Accumulation of anthropogenic and natural radionuclides in bottom sediments of the Northwest Pacific Ocean, Deep-Sea Res. II, 50, 2649-2673, 2003.

Morino, Y., Ohara, T., and Nishizawa, M.: Atmospheric behavior, deposition, and budget of radioactive materials from the Fukushima Daiichi Nuclear Power Plant in March 2011, Geophys. Res. Lett., 38, L00G11, doi:10.1029/2011GL048689, 2011.

Muramatsu, Y., Hamilton, T., Uchida, S., Tagami, K., Yoshida, S., and Robison, W.: Measurement of ${ }^{240} \mathrm{Pu} /{ }^{239} \mathrm{Pu}$ isotopic ratios in soils from the Marshall Islands using ICP-MS, Sci. Toal Environ., 278, 151-159, 2001.

Nagaya, Y. and Nakamura, K.: ${ }^{239,240} \mathrm{Pu}$ and ${ }^{137} \mathrm{Cs}$ in the East China and Yellow Seas, J. Oceanogr., 48, 23-35, 1992.

NIRS (National Institute of Radiological Sciences): Report on Biospheric Assessment for Waste Disposal, 61, 2010 (in Japanese).

Oikawa, S., Watabe, T., Inatomi, N., Isoyama, N., Misonoo, J., Suzuki, C., Nakahara, M., Nakamura, R., Morizono, S., Fujii, S., Hara, T., and Kido, K.: Plutonium isotopes concentration in seawater and bottom sediment off the Pacific coast of Aomori sea area during 1991-2005, J. Environ. Radioact., 102, 302-310, 2011.

Otosaka, S. and Kobayashi, T.: Sedimentation and remobilization of radiocesium in the coastal area of Ibaraki, $70 \mathrm{~km}$ south of the Fukushima Dai-ichi Nuclear Power Plant, Environ. Monit. Assess, in press, doi:10.1007/s10661-012-2956-7, 2012.

Otosaka, S., Amano, H., Ito, T., Kawamura, H., Kobayashi, T., Suzuki, T., Togawa, O., Chaykovskaya, E. L., Lishavskaya, T. S., Novichkov, V. P., Karasev, E. V., Tkalin, A. V., and Volkov, Y. N.: Anthropogenic radionuclides in sediment in the Japan Sea: distribution and transport processes of particulate radionuclides, J. Environ. Radioact., 91, 128-145, 2006.

Perianeez, R., Kyung-Suk, S., and Byung-I1, M.: Should we measure plutonium concentration in marine sediments near Fukushima?, J. Radioanal. Nucl. Chem., in press, doi:10.1007/s10967-013-2422-1, 2013.

Pettersson, H. B. L., Amano, H., Berezhnov, V. I., Chaykovskaya, E., Chumichev, V. B., Chung, C. S., Gastaud, J., Hirose, K., Hong, G. H., Kim, C. K., Kim, S. H., Lee, S. H., Morimoto, T., Nikitin, A., Oda, K., Povinec, P. P., Suzuki, E., Tkalin, A., Togawa, O., Veletova, N. K., Volkov, Y., and Yoshida, K.: Anthropogenic radionuclides in sediments in the NW Pacific Ocean and its marginal seas: results of the 1994-1995 JapaneseKorean-Russian expeditions, Sci. Total Environ., 237/238, 213224, 1999.

Povinec, P., Fowler, S., and Baxter, M.: Chernobyl and the marine environment: the radiological impact in context, IAEA Bulletin, 38, 18-22, 1996.

Sakaguchi, A., Kadokura, A., Steier, P., Tanaka, K., Takahashi, Y., Chiga, H., Matsushima, A., Nakashima, S., and Onda, Y.: Isotopic determination of $\mathrm{U}, \mathrm{Pu}$ and $\mathrm{Cs}$ in environmental waters following the Fukushima Daiichi Nuclear Plant accident, Geochem. J., 46, 355-360, 2012.

Schwantes, J. M., Orton, C. R., and Clark, R. A.: Analysis of a nuclear accident: fission and activation product releases from the Fukushima Daiichi Nuclear Facility as remote indicators of source identification, extent of release, and state of damaged spent nuclear fuel, Environ. Sci. Technol., 46, 8621-8627, 2012. Stohl, A., Seibert, P., Wotawa, G., Arnold, D., Burkhart, J. F., Eckhardt, S., Tapia, C., Vargas, A., and Yasunari, T. J.: Xenon133 and caesium-137 releases into the atmosphere from the Fukushima Dai-ichi nuclear power plant: determination of the source term, atmospheric dispersion, and deposition, Atoms. Chem. Phys., 12, 2313-2343, 2012.

Taylor, R. N., Warneke, T., Milton, J. A., Croudace, I. W., Warwick, P. E., and Nesbitt, R. W.: Plutonium isotope ratio analysis at femtogram to nanogram levels by multicollector ICP-MS, J. Anal. At. Spectrom., 16, 279-284, 2001.

Tsumune, D., Tsubono, T., Aoyama, M., and Hirose, K.: Distribution of oceanic ${ }^{137} \mathrm{Cs}$ from the Fukushima Dai-ichi Nuclear Power Plant simulated numerically by a regional ocean model, J. Environ. Radioact., 111, 100-108, 2012.

UNSCEAR: Sources and Effects of Ionizing Radiation, United Nations Scientific Committee on the Effects of Atomic Radiation Exposures to the Public from Man-made Sources of Radiation, United Nations, New York, 1993.

Wang, Z. L. and Yamada, M.: Plutonium activities and ${ }^{240} \mathrm{Pu} /{ }^{239} \mathrm{Pu}$ atom ratios in sediment cores from the East China Sea and Okinawa Trough: sources and inventories, Earth Planet. Sci. Lett., 233, 441-453, 2005.

Yamada, M. and Nagaya, Y.: ${ }^{239+240} \mathrm{Pu}$ and ${ }^{137} \mathrm{Cs}$ in sediments from Tokyo Bay: distribution and inventory, J. Radioanal. Nucl. Chem., 245, 273-279, 2000.

Yamamoto, M., Yamauchi, Y., Chatani, K., Igarashi, S., Komura, K., and Ueno, K.: Fallout ${ }^{237} \mathrm{~Np}$, Pu isotopes and ${ }^{241} \mathrm{Am}$ in lake and sea sediments from the coastal area of the Sea of Japan, Radiochim. Acta, 51, 85-95, 1990.

Yamamoto, M., Takada, T., Nagao, S., Koike, T., Shimada, K., Hoshi, M., Zhumadilov, K., Shima, T., Fukuoka, M., Imanaka, T., Endo, S., Sakaguchi, A., and Kimura, S.: An early survey of the radioactive contamination of soil due to the Fukushima Daiichi Nuclear Power Plant accident, with emphasis on plutonium analysis, Geochem. J., 46, 341-353, 2012.

Yoshida, N. and Kanda, J.: Tracking the Fukushima radionuclides, Science, 336, 1115-1116, 2012.

Zheng, J. and Yamada, M.: Sediment core record of global fallout and Bikini close-in fallout Pu in Sagami Bay, Western Northwest Pacific Margin, Environ. Sci. Technol., 38, 3498-3504, 2004.

Zheng, J. and Yamada, M.: Vertical distribution of ${ }^{239+240} \mathrm{Pu}$ activities and ${ }^{240} \mathrm{Pu} /{ }^{239} \mathrm{Pu}$ atom ratios in sediment cores: implications for the sources of Pu in the Japan Sea, Sci. Total Environ., 340, 199-211, 2005.

Zheng, J. and Yamada, M.: Inductively coupled plasma-sector field mass spectrometry with a high-efficiency sample introduction system for the determination of $\mathrm{Pu}$ isotopes in settling particles at femtogram levels, Talanta, 69, 1246-1253, 2006a.

Zheng, J. and Yamada, M.: Determination of Pu isotopes in sediment cores in the Sea of Okhotsk and the NW Pacific by sector field ICP-MS, J. Radioanal. Nucl. Chem., 267, 73-83, $2006 \mathrm{~b}$.

Zheng, J. and Yamada, M.: Plutonium isotopes in settling particles: transport and scavenging of $\mathrm{Pu}$ in the western Northwest Pacific, Environ. Sci. Technol., 40, 4103-4108, 2006c.

Zheng, J. and Yamada, M.: Isotope dilution sector-field inductively coupled plasma mass spectrometry combined with extraction chromatography for rapid determination of ${ }^{241} \mathrm{Am}$ in marine sediment samples: a case study in Sagami Bay, Japan, J. Oceanogr. 
64, 541-550, 2008.

Zheng, J., Aono, T., Uchida, S., Zhang, J., and Honda, M. C.: Distribution of Pu isotopes in marine sediments in the Pacific $30 \mathrm{~km}$ off Fukushima after the Fukushima Daiichi nuclear power plant accident, Geochem. J., 46, 361-369, 2012a.
Zheng, J., Tagami, K., Watanabe, Y., Uchida, S., Aono, T., Ishii, N., Yoshida, S., Kubota, Y., Fuma, S., and Ihara, S.: Isotopic evidence of plutonium release into the environment from the Fukushima DNPP accident, Sci. Rep., 2, 1-8, doi:10.1038/srep00304, 2012b. 